\title{
Seasonal trend analysis of carbon dioxide across latitudes of Africa, Europe and Asia
}

\author{
C. M. ANORUO \\ Atmospheric Physics Group, Imo State University Owerri \& Department of Physics and Astronomy, University of \\ Nigeria, Nsukka. \\ Email: anoruochukwuma@gmail.com
}

Received: January 31, 2020; accepted: September 3, 2020

\begin{abstract}
RESUMEN
Las emisiones de carbono van en aumento y aún queda mucho trabajo por hacer para precisar el incremento estacional de este compuesto y garantizar su reducción a corto plazo. Hay una gran necesidad de contar con nuevos métodos para validar las tendencias estacionales del dióxido de carbono $\left(\mathrm{CO}_{2}\right)$. Obtuvimos datos del periodo 2003-2008 referentes a $\mathrm{CO}_{2}$, temperatura e índice diferencial normalizado de vegetación (NVDI, por sus siglas en inglés) del Espectrorradiómetro de Imágenes de Media Resolución (MODIS) instalado a bordo del satélite Terra, para África (Nigeria, Mauritania, Congo y Sudán), Europa (Francia, Finlandia, Turquía y Ucrania) y Asia (China, Mongolia, India y Afganistán). Por primera vez se utilizó el análisis de índices estacionales para validar el índice de vegetación. La estacionalidad del dióxido de carbono se determinó mediante la división del promedio mensual entre la media anual. Adicionalmente se calculó la diferencia porcentual de la relación entre NDVI y $\mathrm{CO}_{2}$ para investigar la influencia subyacente de ambos parámetros y validar el cambio estacional derivado del ciclo de actividad solar. Mediante el agrupamiento de años con base en actividad solar máxima (2003-2004), intermedia (2005-2006) y muy baja (2007-2008), nuestros resultados ayudaron a ampliar la noción física de que la fluctuación del NDVI obedece a la presencia de sumideros regionales de $\mathrm{CO}_{2}$, sobre todo durante los meses equinocciales. Nuestros resultados demuestran que la variación estacional de $\mathrm{CO}_{2}$ depende de la latitud geográfica y los ciclos de actividad solar, lo cual resulta esencial para el estudio de las tendencias futuras de la relación entre $\mathrm{NDVI} \mathrm{y} \mathrm{CO}_{2}$.
\end{abstract}

\begin{abstract}
Carbon-driven emissions are on the rise and much work remains to be done to benchmark seasonal carbon increase and ensure its prompt reduction. There is a great need of new methods for validating seasonal trends of carbon dioxide $\left(\mathrm{CO}_{2}\right)$. We obtained $\mathrm{CO}_{2}$, temperature and normalized difference vegetation index (NDVI) data from the Moderate Resolution Imaging Spectroradiometer (MODIS) instrument onboard the Terra satellite from 2003 to 2008 over Africa (Nigeria, Mauritania, Congo, Sudan), Europe (France, Finland, Turkey, Ukraine), and Asia (China, Mongolia, India, Afghanistan). For the first time, seasonal index analysis was used to validate vegetation index. The seasonality in carbon dioxide was determined dividing the monthly average by the annual mean. Additionally, the percentage difference correlation of the NDVI and $\mathrm{CO}_{2}$ relationship was calculated to investigate the underlying influence of both parameters and validate the seasonal change resulting from the solar activity cycle. By grouping years based on solar activity maximum (2003-2004), intermediate (2005-2006) and very low activity (2007-2008), the results expanded the physical interpretation that seasonal fluctuation of NDVI corresponds to the terrestrial sink of regional $\mathrm{CO}_{2}$, mostly occurring during equinoctial months. Our results demonstrate that seasonal variation of $\mathrm{CO}_{2}$ depends on geographic latitude and the solar activity cycle. This result is essential in studying the future trend relationship between NDVI and $\mathrm{CO}_{2}$.
\end{abstract}

Keywords: geoenvironment, regional carbon trend, climate change, solar activity cycle. 


\section{Introduction}

\subsection{The relationship between normalized difference} vegetation index and carbon dioxide

The use of atmospheric carbon dioxide $\left(\mathrm{CO}_{2}\right)$ seasonal index measures its sources and sinks with high precision. Understanding the seasonal dynamics of these emissions is necessary to enable an effective global mitigation. However, it is difficult to estimate carbon-driven emissions using only direct measurements, in contrast to regional estimation (Le Quere et al., 2009). Komhyr et al. (1989) established that $\mathrm{CO}_{2}$ measurements made at the Mauna Loa Observatory are conducted with great precision. The observatory, which measures the mole fraction of $\mathrm{CO}_{2}$ using infrared absorption, gives quantitative information about its global trend. Kaufmann et al. (2008) used autoregression to test their approach and conclude that measurements based on distance are adequate. This information contradicts the results of Le Quere et al. (2009), who developed a model that effectively replicated the activity of land-ocean $\mathrm{CO}_{2}$ sinks and its impact on the increase of $\mathrm{CO}_{2}$ levels from 2000-2008.

The increase of $\mathrm{CO}_{2}$ sources has been attributed to fossil fuel, and carbon intensity depends on the regional scale (Weber et al., 2008). The interplay between carbon-driven emissions and the resultant climate change effect is already well-known (Plass, 1956; Kaplan, 1960; Tans et al., 1989; Siegenthaler and Sarmiento, 1993; Houghton and Hackler, 1999; Seekell, 2016). An estimation using different model methods has shown that, over the decades, a significant proportion of $\mathrm{CO}_{2}$ released into the atmosphere has been absorbed by the biosphere and oceans (Rayner et al., 1999; Battle et al., 2000; Le Quéré et al., 2003; Manning and Keeling, 2006). The variability in relative carbon sequestration by the two sinks causes variability in the overall $\mathrm{CO}_{2}$ atmospheric loading and, by extension, it produces climate variability and change. The idea of using greening in carbon capture and storage aims to limit the corresponding concentrations and stabilize the Earth's radiative forcing. Prior studies have demonstrated the applications of greening (Bartlett et al., 1990; Hope et al., 1993; Sharkey, 2006; Rigby et al., 2008; Turnbull et al., 2011; McKain et al., 2012; Rogers et al., 2017), therein validating the option as applicable to broader efforts in the mitigation of climate change. Calculating dynamical trends in $\mathrm{CO}^{2}$, temperature and normalized index across the regions of Africa, Europe and Asia would be a worthwhile, relevant exercise. The results of the dynamical trend will provide a possible mitigation strategy. The idea of using greening to regulate surface $\mathrm{CO}_{2}$ storage aims to limit the corresponding increasing frequency of heat waves and stabilize the Earth's radiative forcing. The normalized difference vegetation index (NDVI) uses the quotient of near infrared radiation and visible wavelength radiation. Its usage is in global climate change and environmental issues. NDVI compensates for reflectivity changes at certain frequencies and tracks greening. The degree of greenness ranges from -1 to +1 , where the positive value is indicative of greening. Using the seasonal index to validate the relationship between $\mathrm{CO}_{2}$ and NDVI is not an approach which has been well investigated. There is a robust review of literature from multiple prior analyses, but no one has investigated the interplay between NDVI and $\mathrm{CO}_{2}$ with latitude, seasons and the solar cycle. This paper discusses the current state of understanding of this interplay and attempts to bridge the knowledge gap between seasonal trends of carbon and their possible mitigation strategy.

Dagg and Lafleur (2014) estimated the NDVI and $\mathrm{CO}_{2}$ relationship over tundra vegetation regions. Their study used a portable chamber to measure $\mathrm{CO}_{2}$ fluxes and a handheld infrared camera for the estimation of NDVI and $\mathrm{CO}_{2}$ variations and their contribution to the understanding of landscape characteristics. They found a positive correlation of $\mathrm{CO}_{2}$ exchange over NDVI, and concluded that NDVI is a good predictor of $\mathrm{CO}_{2}$ exchange. In an attempt to estimate global $\mathrm{CO}_{2}$ concentration using MODIS, Guo et al. (2012) used a model to investigate the carbon cycle between biosphere and atmosphere combined with an observation from eddy covariance. Although the study covered a short period (20092011), it aimed to map monthly $\mathrm{CO}_{2}$ concentrations over Africa, Eurasia, and North and South America using vegetation cover. The results indicate that seasonal trends of $\mathrm{CO}_{2}$ have local variations and their maxima and minima occur during summer and winter, respectively, over Eurasia, while the fluctuations over Africa were quite small. The study, which also features other parameters, found that land surface temperature has a better potential for validating $\mathrm{CO}_{2}$ concentration trends. La-Puma et al. (2007) found a good relationship between NDVI and $\mathrm{CO}_{2}$ during the 
summer, when biomass reaches its peak. Their results suggest that NDVI should not be included in model calibration over $\mathrm{CO}_{2}$ fluxes. These results conflict with Cihlar et al. (1992), who measured NDVI and $\mathrm{CO}_{2}$ interactions from an aircraft over agricultural lands in Kansas, finding that their relationship was linearly correlated over a single day, but nonlinearly over a longer period. Stow et al. (1998) found similar results and suggested that NDVI is a good parameter to predict variations in $\mathrm{CO}_{2}$. The same results were corroborated in other studies (McMichael, 1999; Markon and Peterson, 2002; Boelman et al., 2003). However, some authors (Huete et al., 2002; Xiao et al., 2004) gave more credit to an enhanced vegetation index (EVI). Lim et al. (2004) suggested that NVDI and $\mathrm{CO}_{2}$ data correlation should not be done directly, for it does not give a better result. Their results show that $\mathrm{CO}_{2}$ and NDVI have a strong seasonal covariance.

\section{Methodology and data source}

In this study, validation of the seasonal variations of $\mathrm{CO}_{2}$ under the influence of NDVI using a seasonal index method of analysis and trend with temperature were validated. The data used in this study were retrieved from the National Aeronautics and Space Administration (NASA GESDISC) via https://giovanni.gsfc.nasa.gov. $\mathrm{CO}_{2}$ concentration was retrieved in parts per million (ppm) from an atmospheric infrared sounder (AIRS) with monthly temporal resolution and $2^{\circ} \times 2.5^{\circ}$ spatial resolution (ID AIRX3C2M v. 005), and temperature with monthly temporal resolution and $1^{\circ}$ spatial resolution (ID AIRX3STM v. 006). NDVI data with monthly temporal resolution and $0.05^{\circ}$ spatial resolution was retrieved from MODIS-Terra for the period 2003-2008 over the study area (Fig. 1), which comprises Africa (Nigeria, Mauritania, Congo, Sudan), Europe (France, Finland, Turkey, Ukraine), and Asia (China, Mongolia, India, Afghanistan). Since the AIRS collection of $\mathrm{CO}_{2}$ data was discontinued in 2012, the corresponding active solar years were used in the analysis. AIRS is an essential tool for the study of $\mathrm{CO}_{2}$ distribution. The seasonal index was obtained by dividing the yearly mean for each monthly period (Eq. [1]); however, a difference correlation of NVDI-CO in percentage was placed to investigate the underlying covariance of both parameters and validate the season- al change, maintaining the solar activity cycle. The method described in Ferreira et al. (2003) was adopted to examine the spectral seasonal index of $\mathrm{CO}_{2}$ over the selected regions. The regions in study vary regarding their meteorological cycles; therefore, the idea of using seasonality is to characterize its temperature variation, which gives a better insight for making new advances.

$$
\Delta_{\mathrm{CO}_{2}}=\left(\mathrm{CO}_{2_{\text {monthly }}} / \mathrm{CO}_{2_{\text {annual aveg }}}\right) / 100 \%
$$

The aim is to validate the $\mathrm{CO}_{2}$ variation as a function of vegetation index by grouping the years based on maximum (2003-2004), intermediate (2005-2006) and very low (2007-2008) solar activity. Table I presents the coordinates of the study locations. The study regions have different meteorological characteristics and different $\mathrm{CO}_{2}$ concentrations, resulting from local biomass burning. Therefore, for a broader view, a larger study region will provide adequate results in characterizing the seasonal trend of $\mathrm{CO}_{2}$. Correlation analysis will reveal if there is any distinctive characteristic in the spatial heterogeneities of either variable, as well as temporal evolution from seasons to years as seen in Eq (2). Chen et al. (2001) used a similar approach to validate seasonal changes in the increase/decrease of $\mathrm{CO}_{2}$ concentrations.

$r_{x y}=\frac{\sum_{i=1}^{n}\left(x_{N D V I}-\bar{x}\right)\left(y_{C O 2}-\bar{y}\right)}{\sqrt{\sum_{i=1}^{n}\left(x_{N D V I}-\bar{x}\right)^{2}} \cdot \sqrt{\sum_{i=1}^{n}\left(y_{C O 2}-\bar{y}\right)^{2}}}$

where $n$ is the number of variables, $\sum x y$ is the sum of the product of the paired NDVI and $\mathrm{CO}_{2}$ variables, $\sum x$ is the sum of NDVI variables, $\sum y$ is the sum of $\mathrm{CO}_{2}$ variables, $\sum x^{2}$ is the sum of squared $x$ variables, $\sum y^{2}$ is the sum of $y$ variables, and $r$ stands for correlation.

\section{Results and discussion}

An adequate validation of the seasonal $\mathrm{CO}_{2}$ trend requires a broader regional sampling technique. This section discusses the scientific approach based on the region and presents new and deeper understanding of the NDVI and $\mathrm{CO}_{2}$ trend analysis as suggested by Lim et al. (2004). However, to obtain a significant result, the direct use of NDVI and $\mathrm{CO}_{2}$ data is not appropriate. The significance of this result shows clearly that seasonal trend analysis is potentially useful to study NDVI and $\mathrm{CO}_{2}$ variations and report the interactions on a regional basis. 


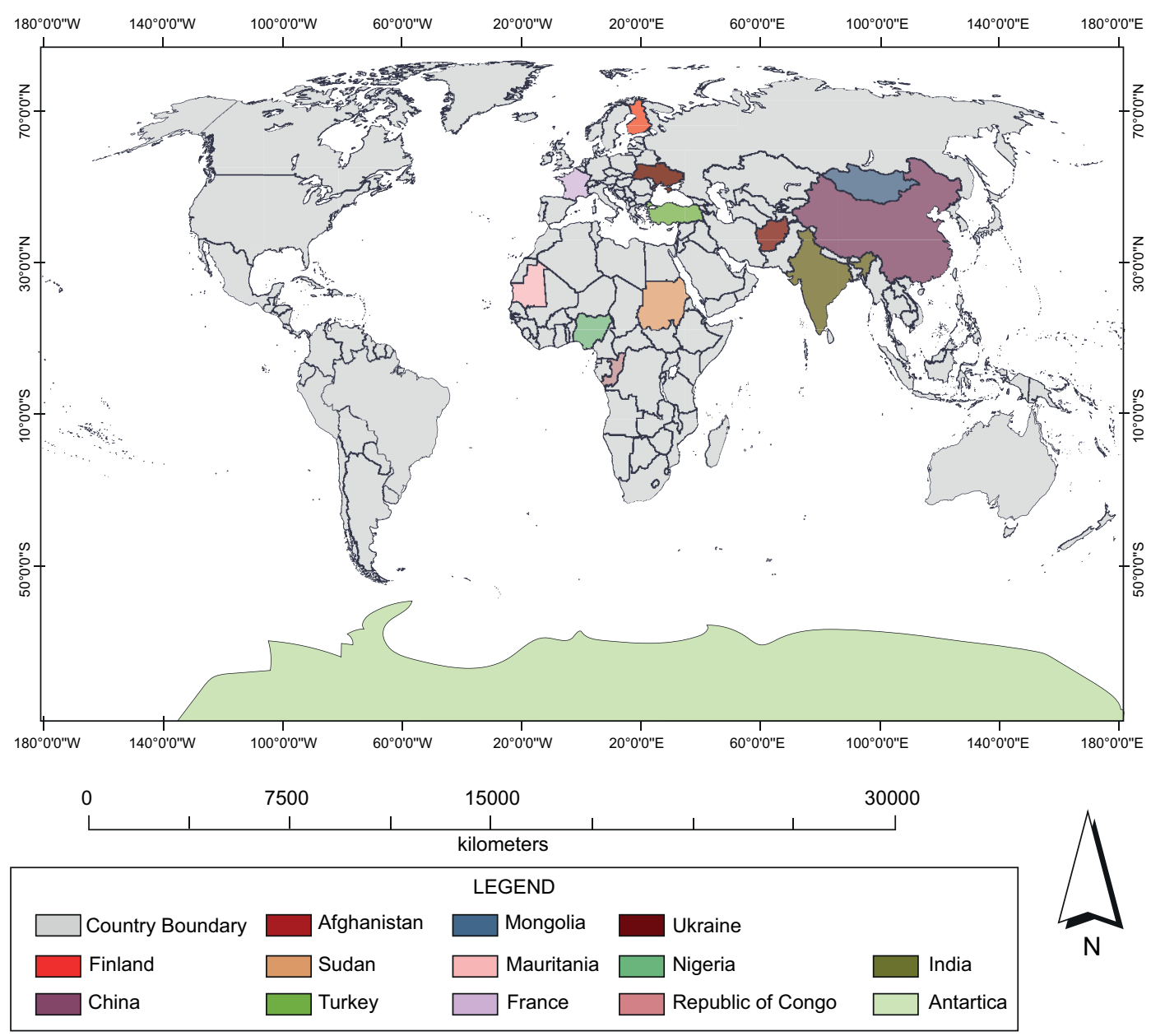

Fig. 1. Georeferencing of the study area.

Table I. Summary of the study locations.

\begin{tabular}{lcc}
\hline Station & Latitude & Longitude \\
\hline Nigeria & $9.0820^{\circ} \mathrm{N}$ & $8.6753^{\circ} \mathrm{E}$ \\
Mauritania & $21.0079^{\circ} \mathrm{N}$ & $10.9408^{\circ} \mathrm{W}$ \\
Congo & $4.0383^{\circ} \mathrm{S}$ & $21.7587^{\circ} \mathrm{E}$ \\
Sudan & $12.8628^{\circ} \mathrm{N}$ & $30.2176^{\circ} \mathrm{E}$ \\
France & $46.2276^{\circ} \mathrm{N}$ & $2.2137^{\circ} \mathrm{E}$ \\
Finland & $61.9241^{\circ} \mathrm{N}$ & $25.7482^{\circ} \mathrm{E}$ \\
Turkey & $38.9637^{\circ} \mathrm{N}$ & $35.2433^{\circ} \mathrm{E}$ \\
Ukraine & $48.3794^{\circ} \mathrm{N}$ & $31.1656^{\circ} \mathrm{E}$ \\
China & $35.8617^{\circ} \mathrm{N}$ & $104.1954^{\circ} \mathrm{E}$ \\
Mongolia & $46.8625^{\circ} \mathrm{N}$ & $103.8467^{\circ} \mathrm{E}$ \\
India & $20.5937^{\circ} \mathrm{N}$ & $78.9629^{\circ} \mathrm{E}$ \\
Afghanistan & $33.9391^{\circ} \mathrm{N}$ & $67.7100^{\circ} \mathrm{E}$ \\
\hline
\end{tabular}

\subsection{Africa}

Validations of the NDVI and $\mathrm{CO}_{2}$ relationship in different seasons over Africa are presented. Figure $2 \mathrm{a}$ shows a $\mathrm{CO}_{2}$ peak during winter, indicating high carbon concentrations; conversely, the incident photosynthetic uptake as the result of carbon storage via greening leads to a decline. Figure $2 b$, c shows the mass uptake of $\mathrm{CO}_{2}$ during the summer, which does not compensate the emission increase of this compound, leading as a result to a net accumulation of carbon. The inverse correlation of $\mathrm{CO}_{2}$ with NDVI indicates that this a good mitigation strategy to limit the concentration of carbon. Curtis and Wang (1998) obtained similar results and suggested an appropriate mitigation of $\mathrm{CO}_{2}$. In our results, NDVI and $\mathrm{CO}_{2}$ are positively correlated during the ascending solar activity cycle (Table II), indicating that NDVI records moderate values towards low emission of carbon. The growth in carbon concentration implies larger anthropogenic emission activities in Nigeria, corresponding to low greening. The results of this study also fill the 

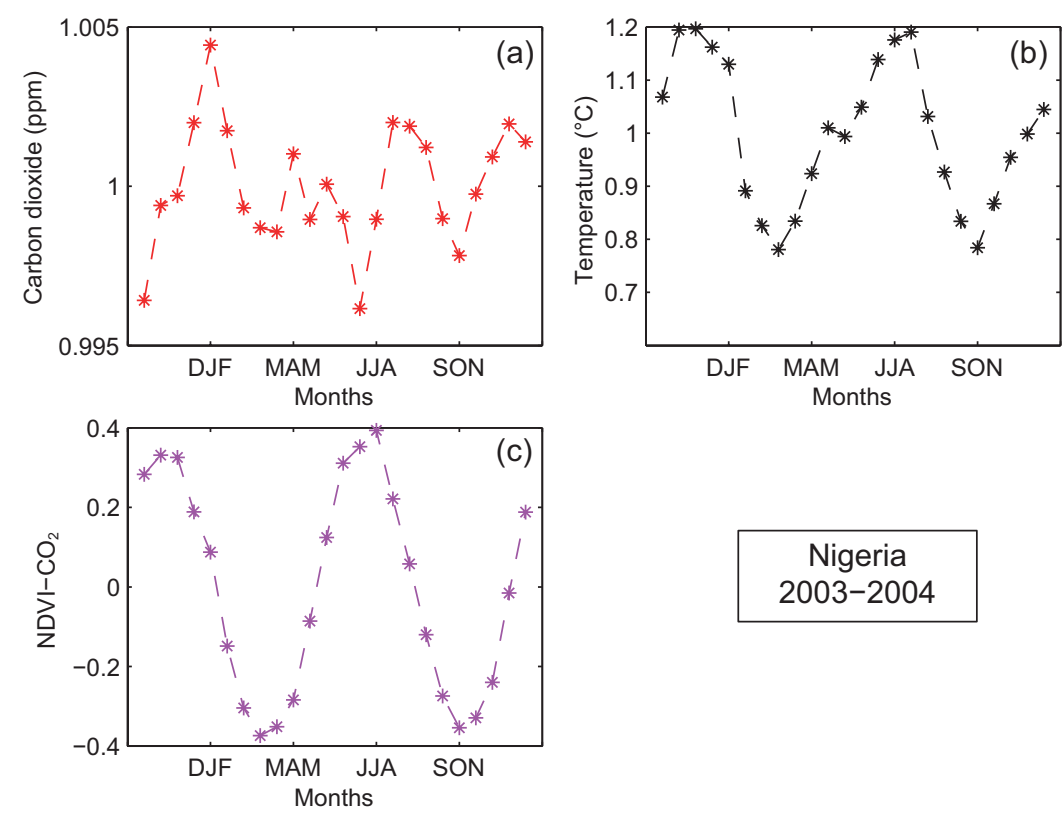

Fig. 2. Seasonal trend of the $\mathrm{CO}_{2}$ and NDVI relationship with temperature over Nigeria during the ascending solar activity cycle.

knowledge gap discussed in Le Quere et al. (2009) regarding a year to year anthropogenic-driven $\mathrm{CO}_{2}$ emission rate. There is a substantial degree of variation in the degree of $\mathrm{CO}_{2}$ effect on temperature; however, the photosynthetic capacity during the growing season closely tracked the pace of warming and the temperature record shows convincingly that Africa has experienced the largest warming rate.

Table II. Correlation index (Africa).

\begin{tabular}{ccc}
\hline Station & \multicolumn{2}{c}{ NDVI and $\mathrm{CO}_{2}$} \\
\hline \multicolumn{3}{c}{ Nigeria } \\
$2003-2004$ & & 0.03 \\
$2005-2006$ & & 0.73 \\
$2007-2008$ & -0.36 \\
& Mauritania & -0.44 \\
$2003-2004$ & & -0.54 \\
$2005-2006$ & & -0.67 \\
$2007-2008$ & & 0.18 \\
\multicolumn{2}{c}{ Congo Kinshasa } \\
$2003-2004$ & & 0.02 \\
$2005-2006$ & & 0.22 \\
$2007-2008$ & Sudan & -0.08 \\
$2003-2004$ & & -0.13 \\
$2005-2006$ & & -0.28 \\
$2007-2008$ & & \\
\hline
\end{tabular}

Towards the intermediate solar activity, Figure 3a, b shows a decreasing trend of NDVI and an increase of $\mathrm{CO}_{2}$ during summer. This is an indicator of weak radiant energy, as displayed in Table II, which indicates a negative weak correlation of NDVI with $\mathrm{CO}_{2}$ and a strong correlation of $\mathrm{CO}_{2}$ as function of NDVI. However, towards the vernal and autumnal equinoxes, $\mathrm{CO}_{2}$ decreases with maximum NDVI at the corresponding months, manifesting a positive correlation. A similar result is seen in Barchivich et al. (2013), and it could therefore be concluded that anthropogenic carbon emission is seasonally dependent. In the descending solar activity cycle as seen in Table II and Figure $4 \mathrm{a}, \mathrm{b}, \mathrm{CO}_{2}$ reaches peaks during winter and summer, corresponding to a declining trend of NDVI at particular seasons. In Figure 5a, Mauritania displays a moderate $\mathrm{CO}_{2}$ concentration trend, while NDVI peaks during the vernal and autumnal seasons, indicating a reduced value of $\mathrm{CO}_{2}$ as seen in Figure 5a, b. However, in Figure 6a, b, the $\mathrm{CO}_{2}$ concentration reaches its maximum during the winter and summer, as seen during the intermediate solar activity year. Figure $7 \mathrm{a}, \mathrm{b}$ shows similar results to Figure $5 \mathrm{a}, \mathrm{b}$, but varies in regard to the carbon storage rate. This shows that NDVI and $\mathrm{CO}_{2}$ variations strongly depend on seasonality. 

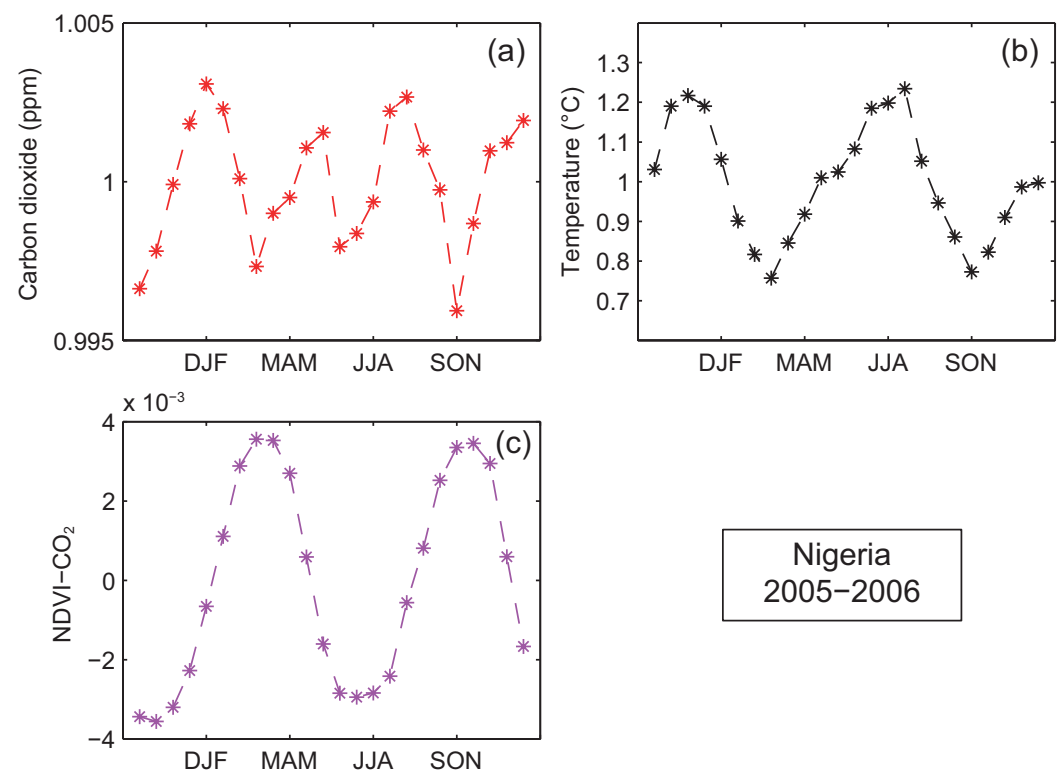

\section{Nigeria 2005-2006}

Fig. 3. Seasonal trend of the $\mathrm{CO}_{2}$ and NDVI relationship with temperature over Nigeria, during the intermediate solar activity cycle.
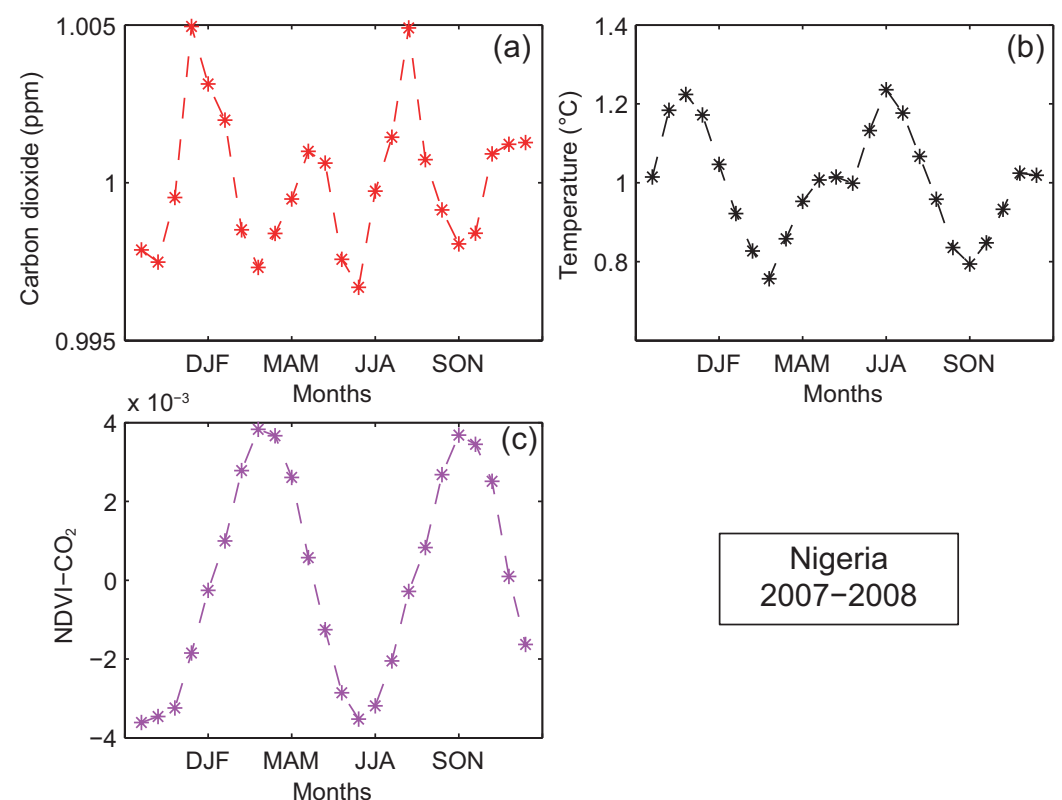

Nigeria

2007-2008

Fig. 4. Seasonal trend of the $\mathrm{CO}_{2}$ and NDVI relationship with temperature over Nigeria during the weak solar activity cycle. 

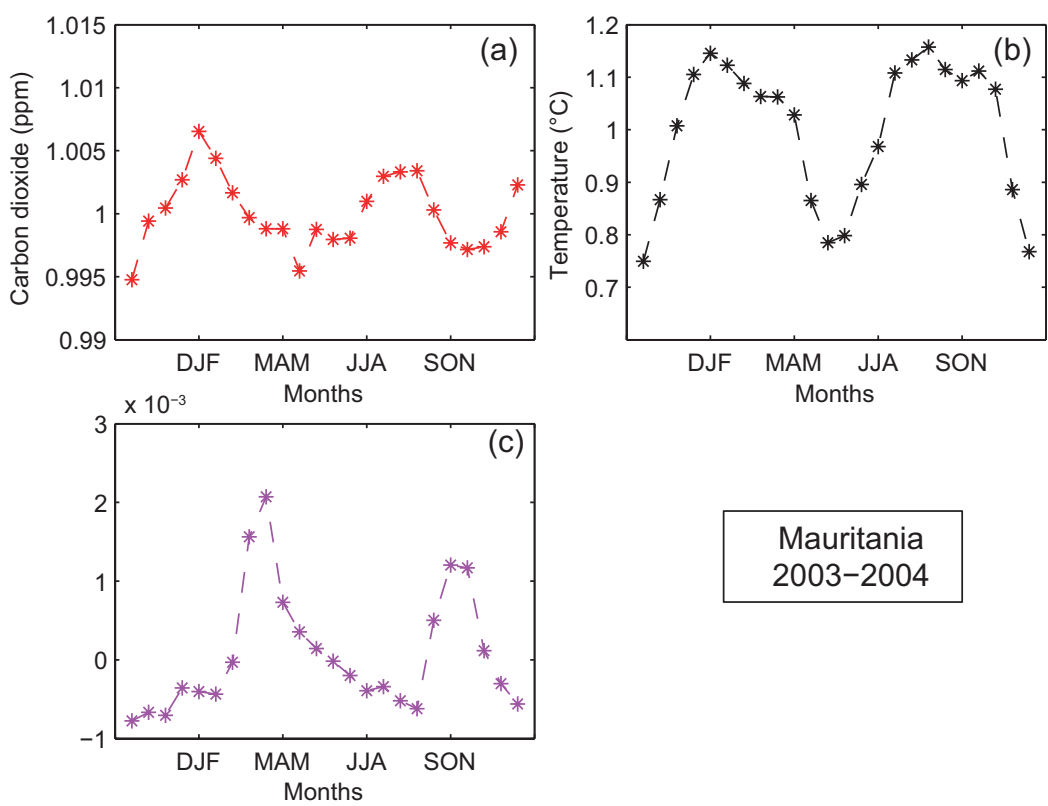

(c)

Fig. 5. Seasonal trend the $\mathrm{CO}_{2}$ and NDVI relationship with temperature over Mauritania during the ascending solar activity cycle.

Seasonal signatures in the atmospheric concentration of $\mathrm{CO}_{2}$ reflect the changing balance of photosynthetic rate; however, biomass burning accounts for the annual cycle of $\mathrm{CO}_{2}$ increase. This result agrees with those of Markon and Peterson (2002). The $\mathrm{CO}_{2}$ and NDVI relationship rate indicates an inverse correlation (Table II). This indicates that the $\mathrm{CO}_{2}$ concentration rate is a landscape dynamic
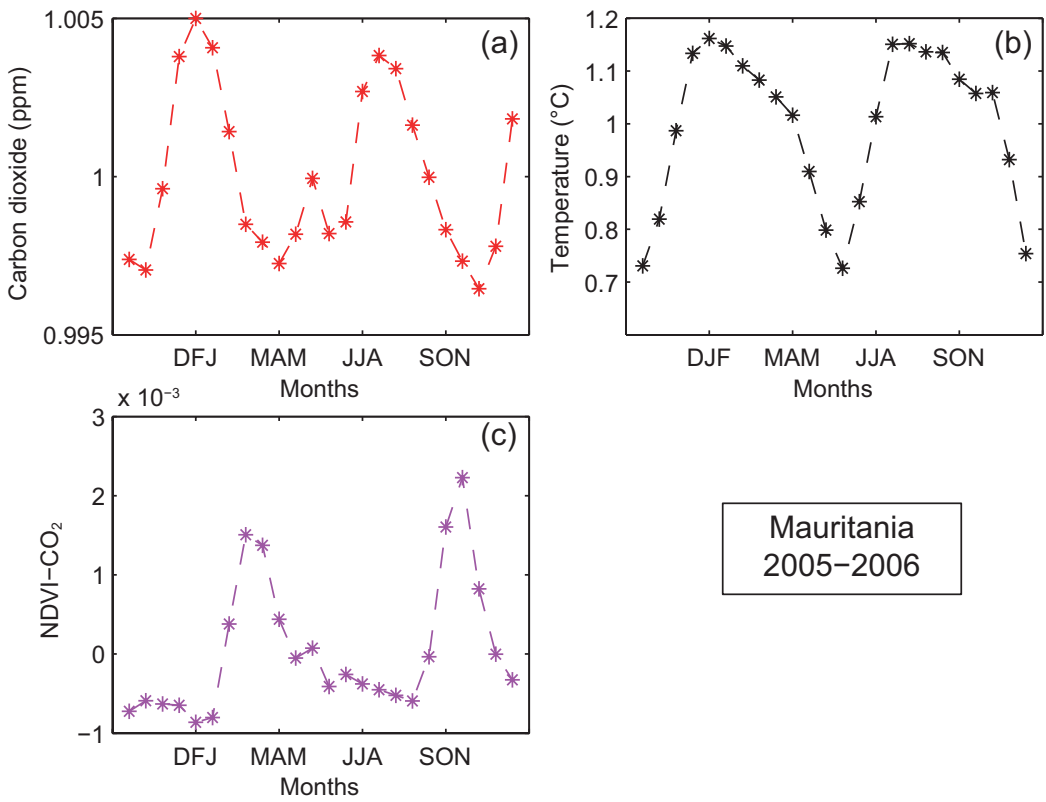

\section{Mauritania} 2005-2006

Fig. 6. Seasonal trend of the $\mathrm{CO}_{2}$ and NDVI relationship with temperature over Mauritania during the intermediate solar activity cycle. 

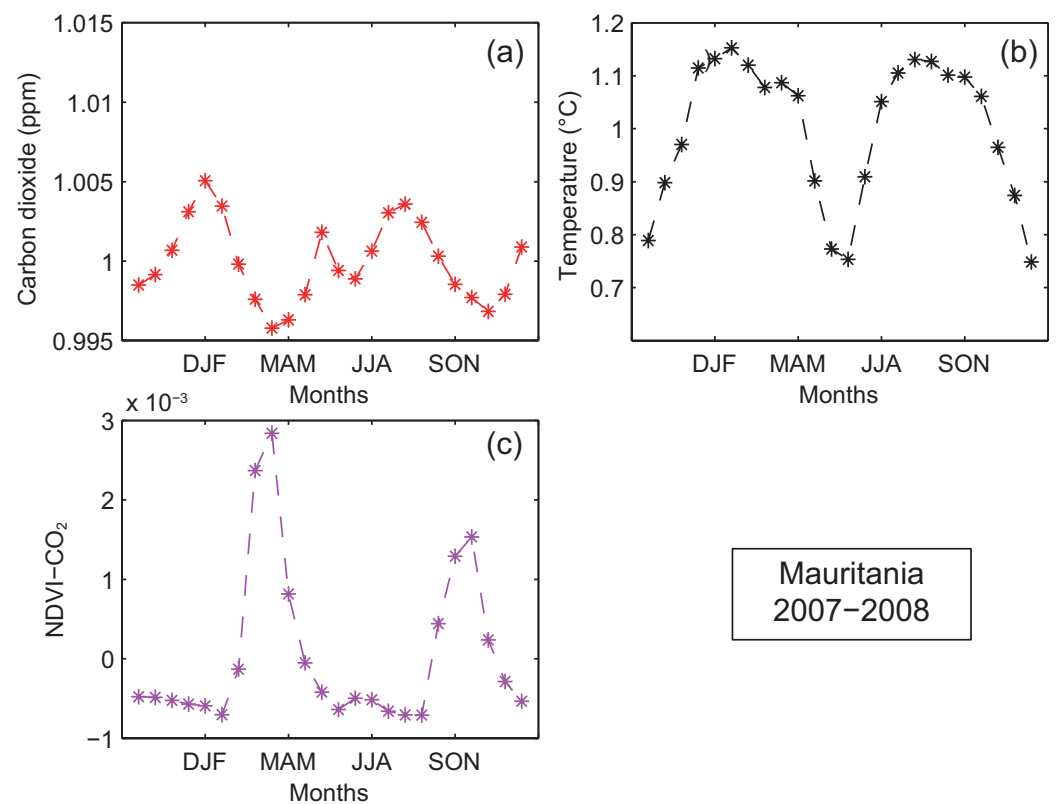

Mauritania

2007-2008

Fig. 7. Seasonal trend of the $\mathrm{CO}_{2}$ and NDVI relationship with temperature over Mauritania during the weak solar activity cycle.

scale and depends on the seasons, which is shown in Figures $6 \mathrm{a}, \mathrm{b}$ to $10 \mathrm{a}, \mathrm{b}$. The seasonal responses of NDVI depend on the atmospheric conditions, as depicted in Figures 11a to 13b. In Figure 11a,
Sudan shows low concentrations of $\mathrm{CO}_{2}$ due to a high vegetation index during the ascending solar activity cycle, as depicted in Figure 11b, but also shows a reciprocal relation in Figure 13a, b.
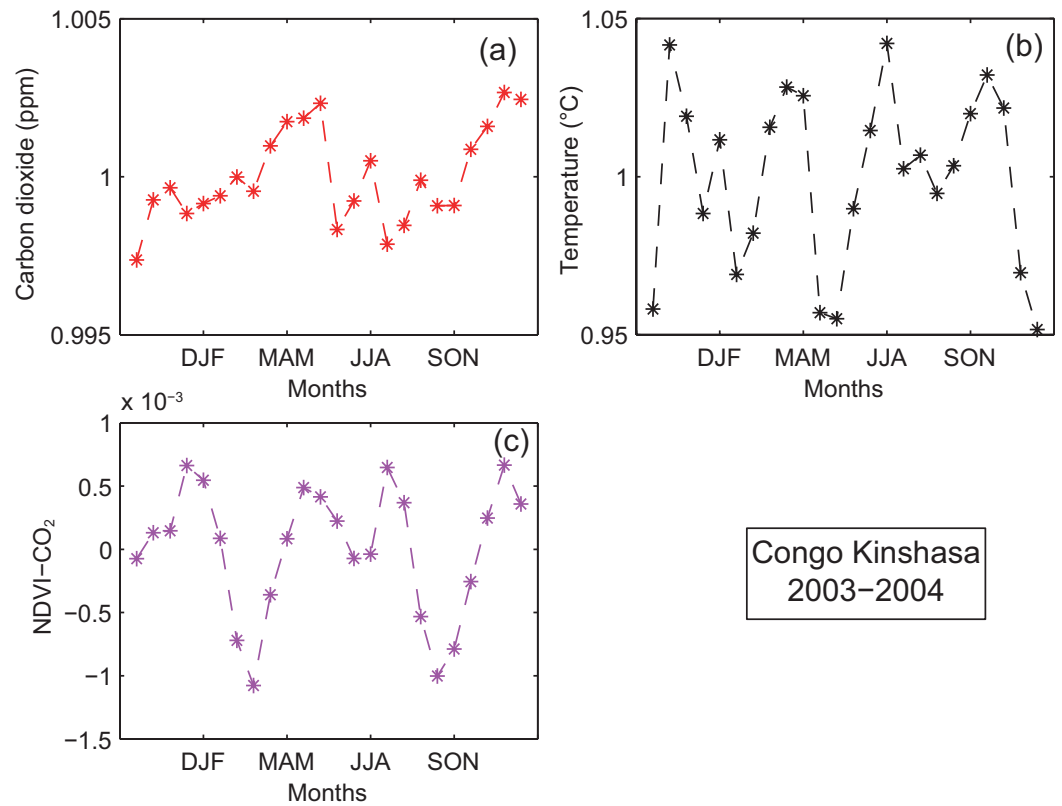

Congo Kinshasa 2003-2004

Fig. 8. Seasonal trend of the $\mathrm{CO}_{2}$ and NDVI relationship with temperature over Congo during the ascending solar activity cycle. 

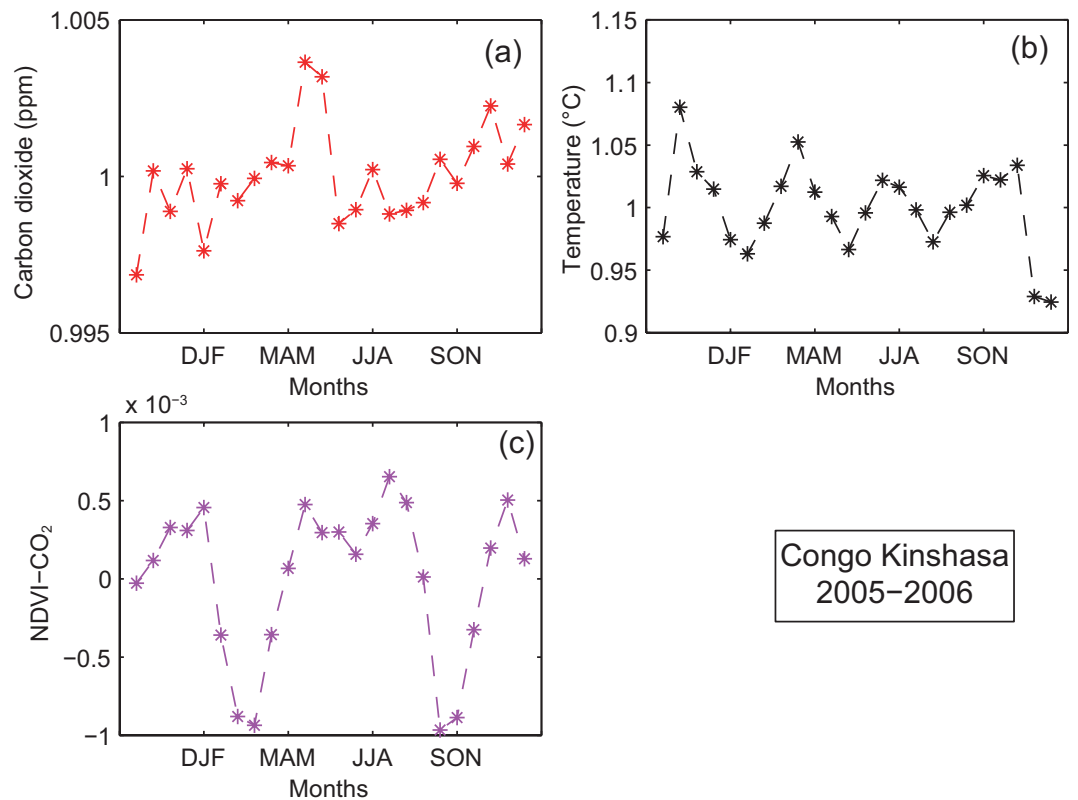

Congo Kinshasa 2005-2006

Fig. 9. Seasonal trend of the $\mathrm{CO}_{2}$ and NDVI relationship with temperature over Congo during the intermediate solar activity cycle.
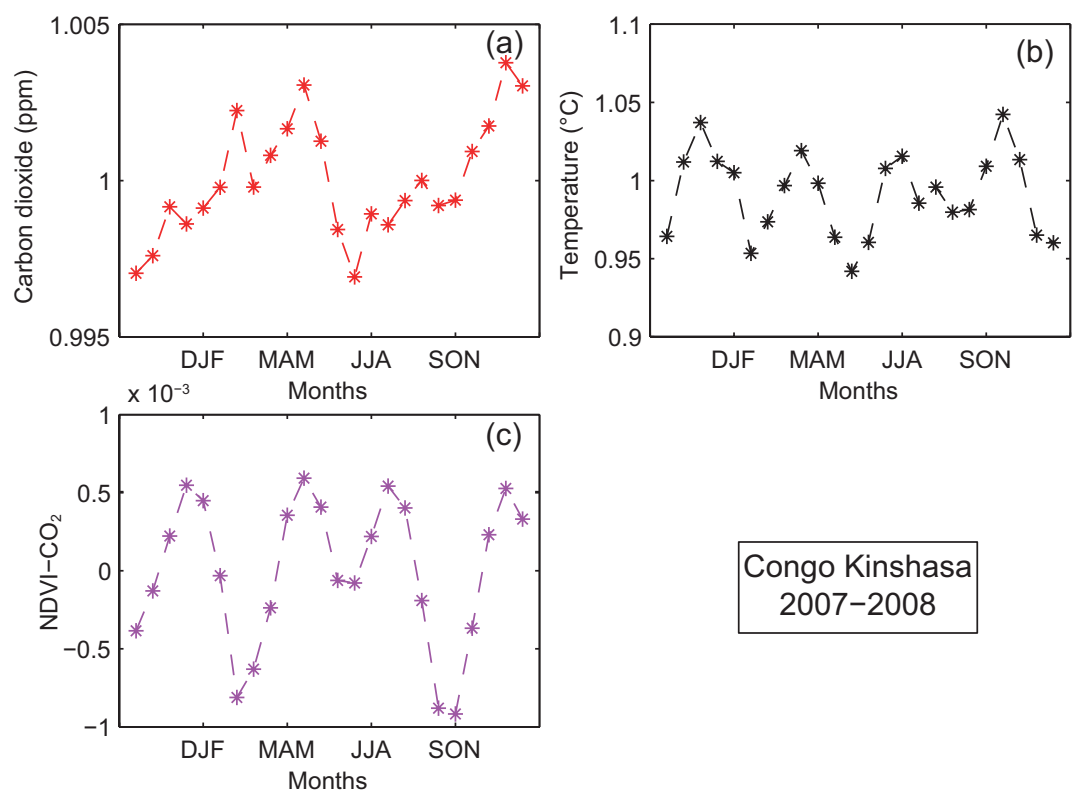

Congo Kinshasa

2007-2008

Fig. 10. Seasonal trend of the $\mathrm{CO}_{2}$ and NDVI relationship with temperature over Congo during the weak solar activity cycle. 

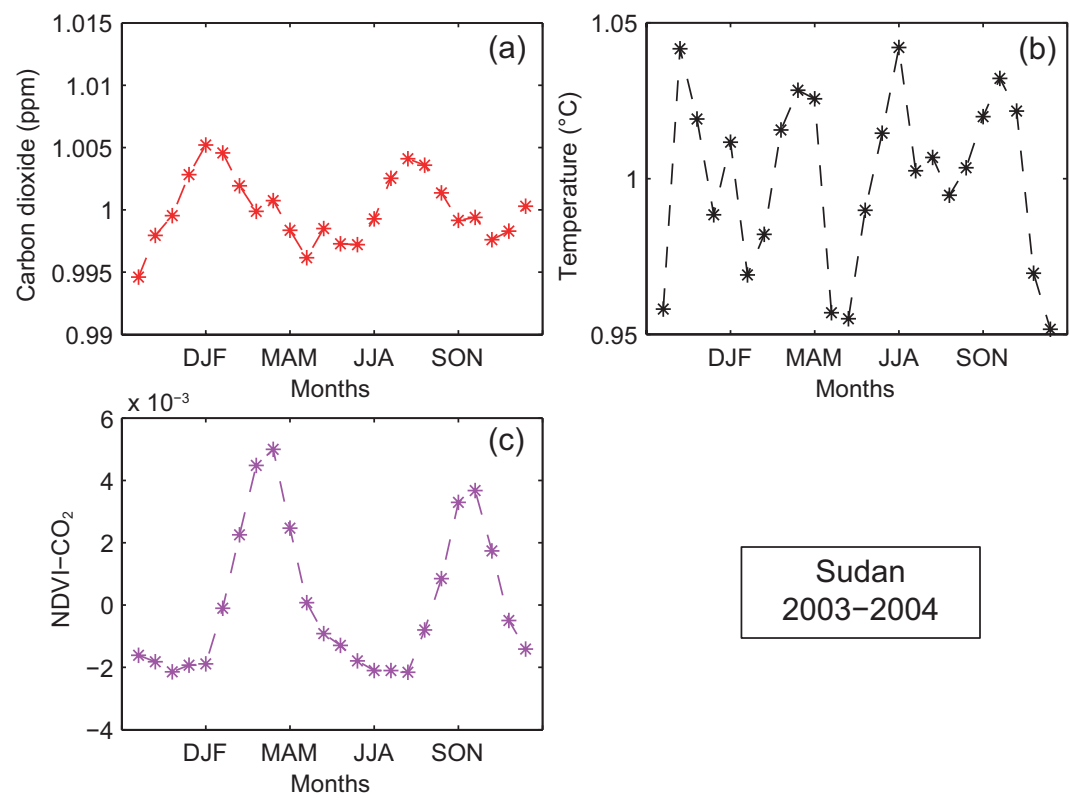

2003-2004

Fig. 11. Seasonal trend of the $\mathrm{CO}_{2}$ and NDVI relationship with temperature over Sudan during the ascending solar activity cycle.
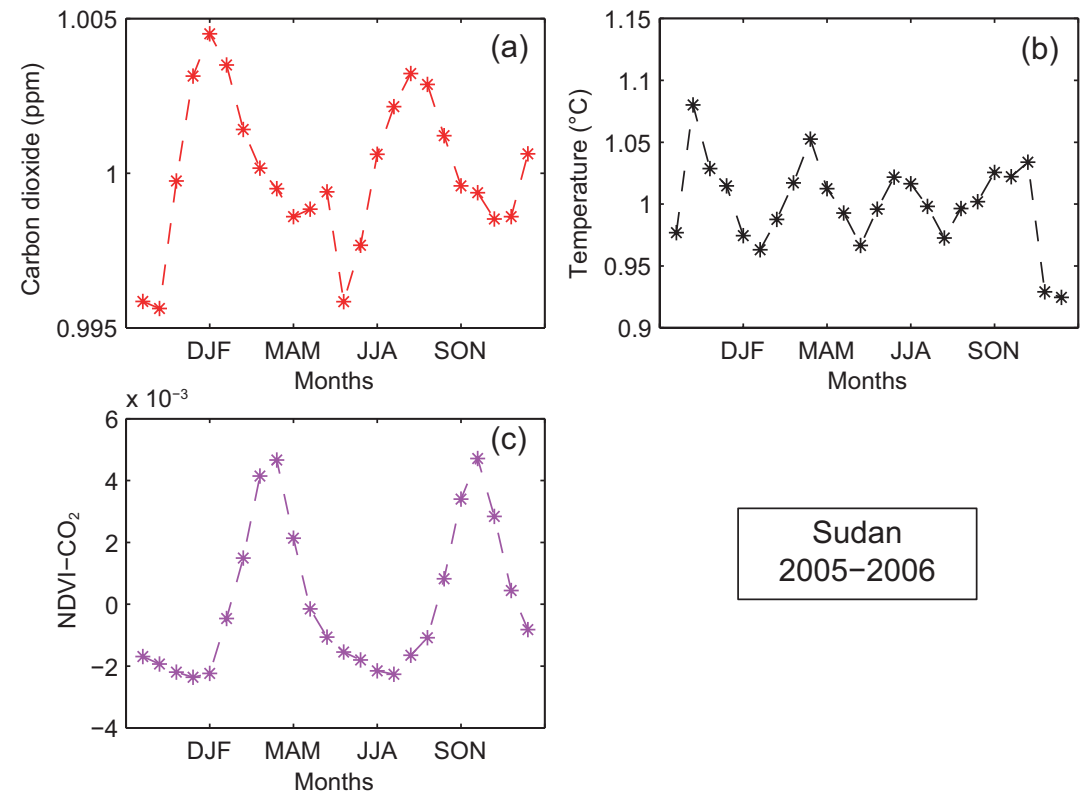

Sudan 2005-2006

Fig. 12. Seasonal trend of the $\mathrm{CO}_{2}$ and NDVI relationship with temperature over Sudan during the intermediate solar activity cycle. 

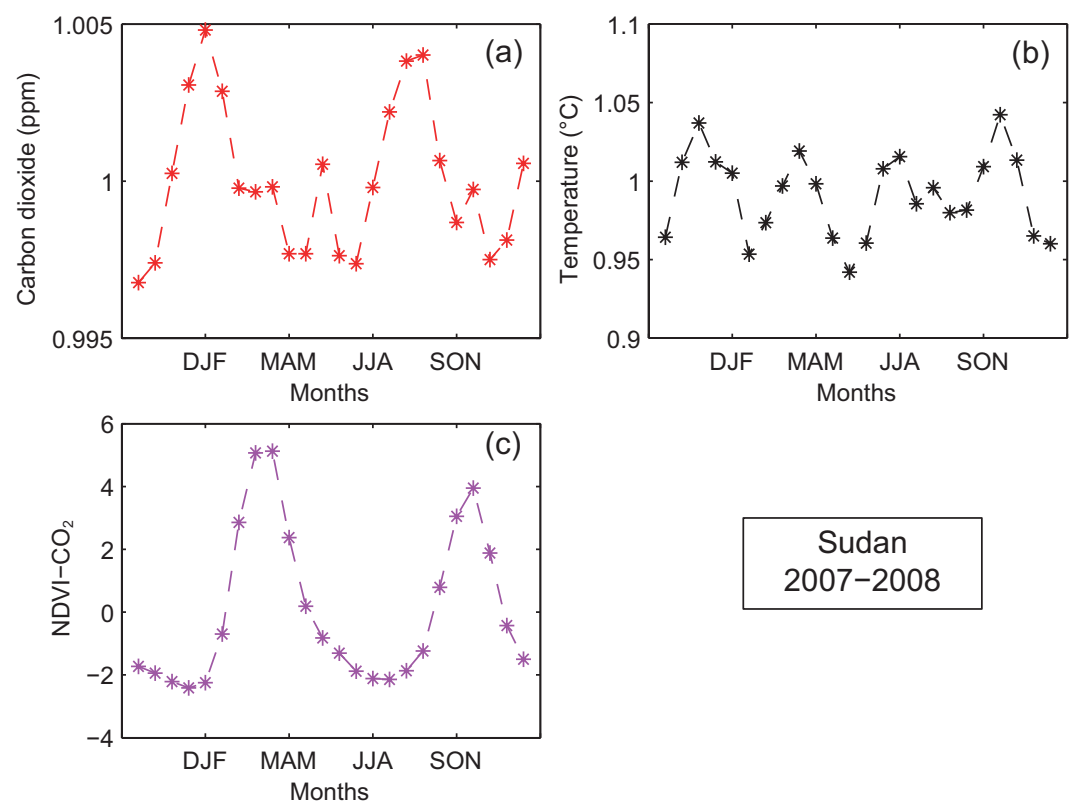

Fig. 13. Seasonal trend of the $\mathrm{CO}_{2}$ and NDVI relationship with temperature over Sudan during the weak solar activity cycle.

\subsection{Europe}

The increasing or decreasing trend of $\mathrm{CO}_{2}$ is the major determinant of climate change. However, to validate this relationship, Figure 14a, b indicates a moderate
$\mathrm{CO}_{2}$ concentration. This clearly shows that during the ascending solar activity cycle, the emission-driven $\mathrm{CO}_{2}$ was regulated. A similar result is depicted in Figure $15 \mathrm{a}, \mathrm{b}$, which shows carbon capture during
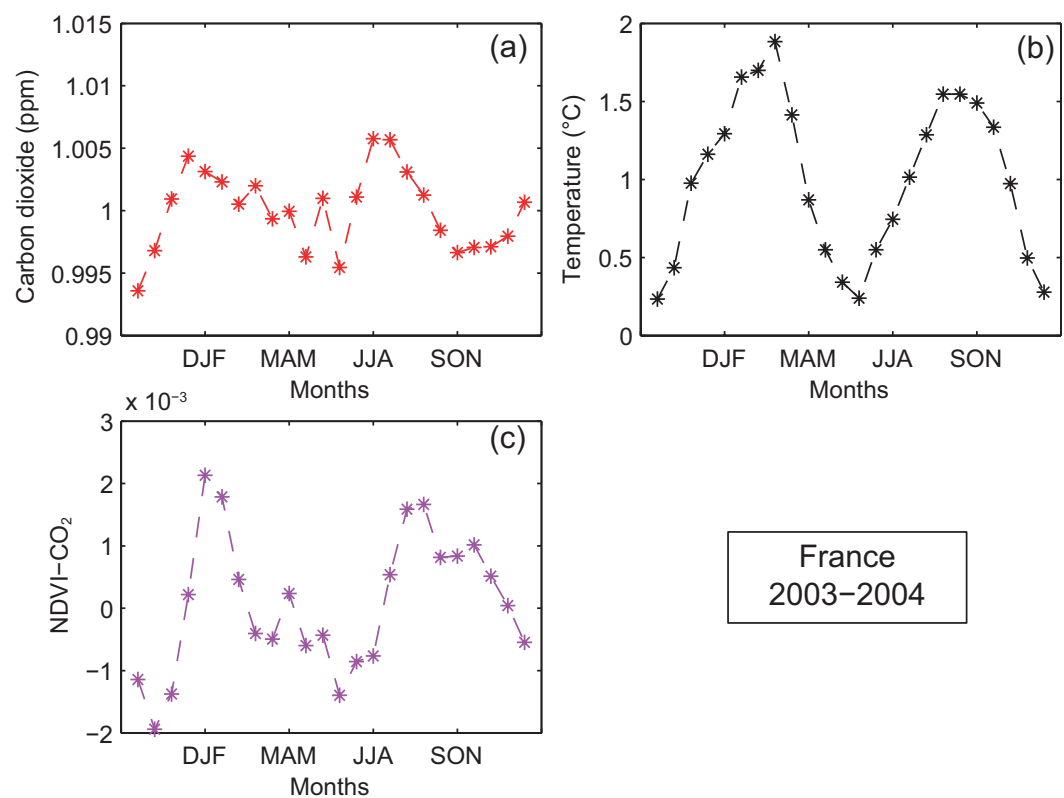

France 2003-2004

Fig. 14. Seasonal trend of the $\mathrm{CO}_{2}$ and NDVI relationship with temperature over France during the ascending solar activity cycle. 
both winter and summer. In Figure 16 a there is a $\mathrm{CO}_{2}$ peak and a drastic increase in the vegetation index. Table II displays a positive weak correlation between NDVI and $\mathrm{CO}_{2}$. The decline in $\mathrm{CO}_{2}$ resulting from NDVI increases is shown in Figures 16a to 19a. In
Figures $20 \mathrm{a}$ to $22 \mathrm{a}$, during the ascending, intermediate and weak solar activity, Turkey experiences maximum emissions of $\mathrm{CO}_{2}$ during winter and summer, which results from heating of the region, as confirmed in Figure 20b. This leads to the conclusion that high
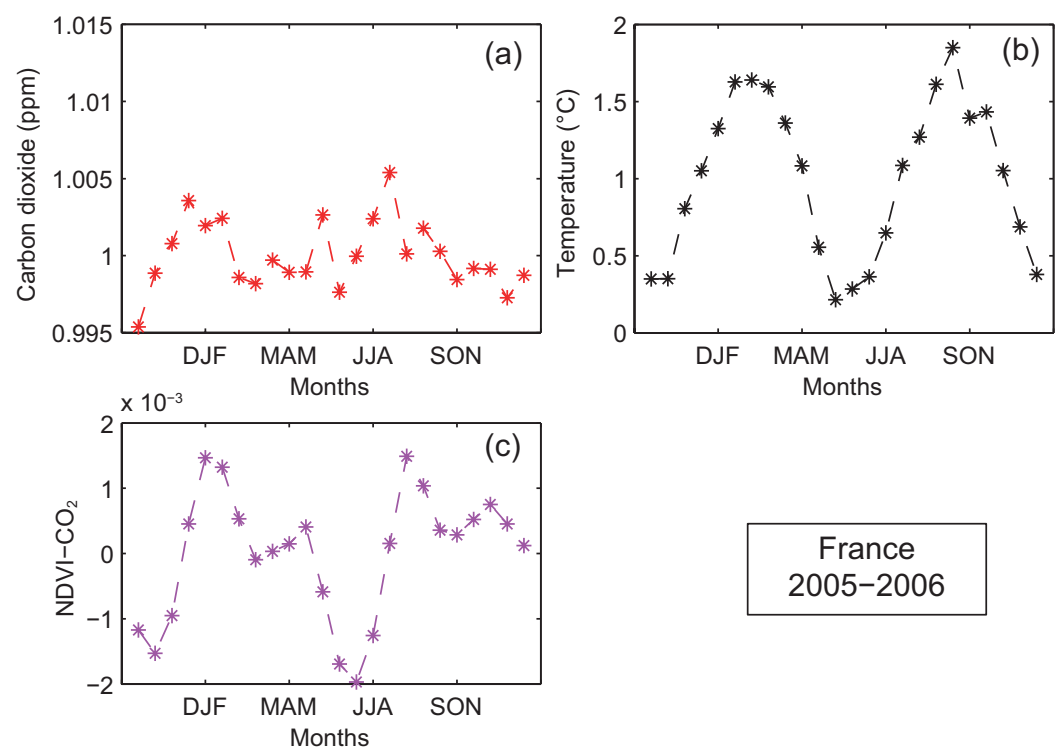

France 2005-2006

Fig. 15. Seasonal trend of the $\mathrm{CO}_{2}$ and NDVI relationship with temperature over France during the intermediate solar activity cycle.
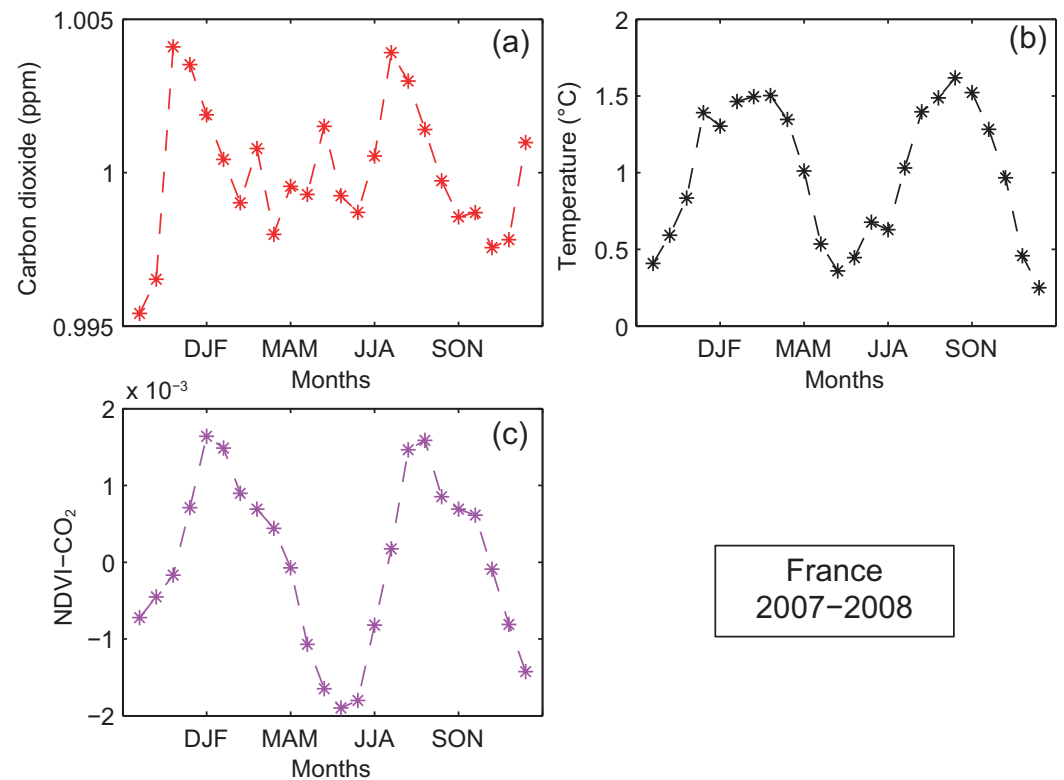

Fig. 16. Seasonal trend of the $\mathrm{CO}_{2}$ and NDVI relationship with temperature over France during the weak solar activity cycle. 

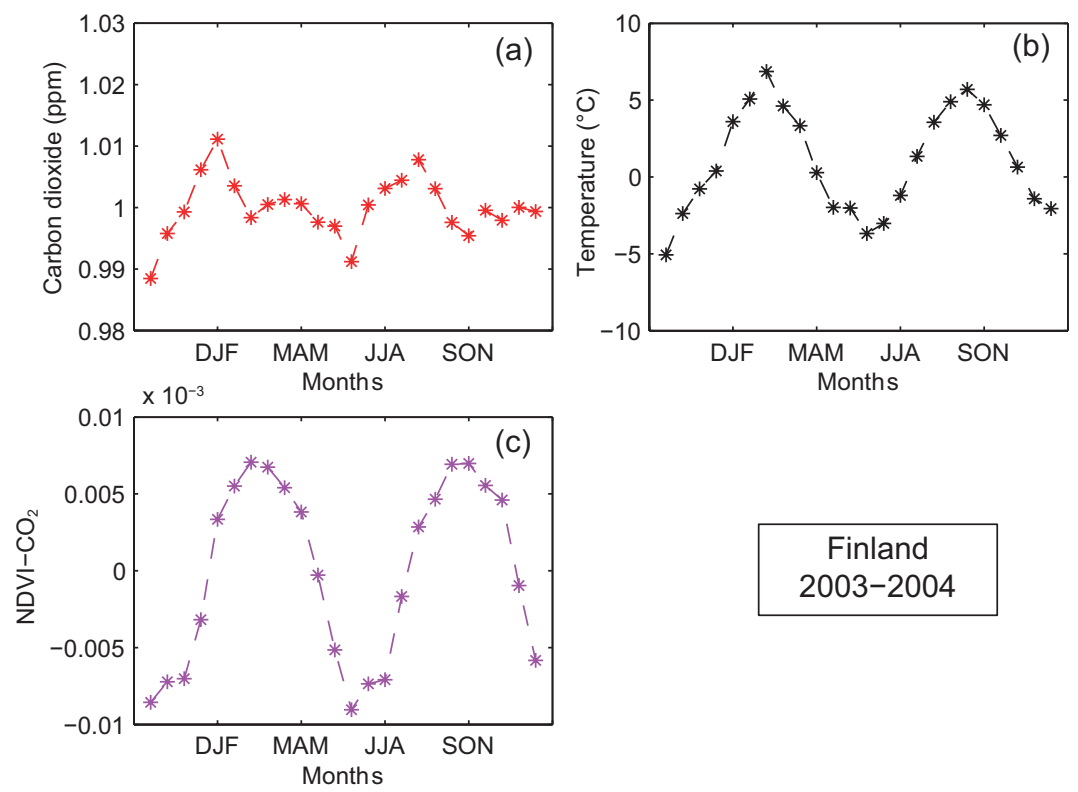

Finland 2003-2004

Fig. 17. Seasonal trend of the $\mathrm{CO}_{2}$ and NDVI relationship with temperature over Finland during the ascending solar activity cycle.
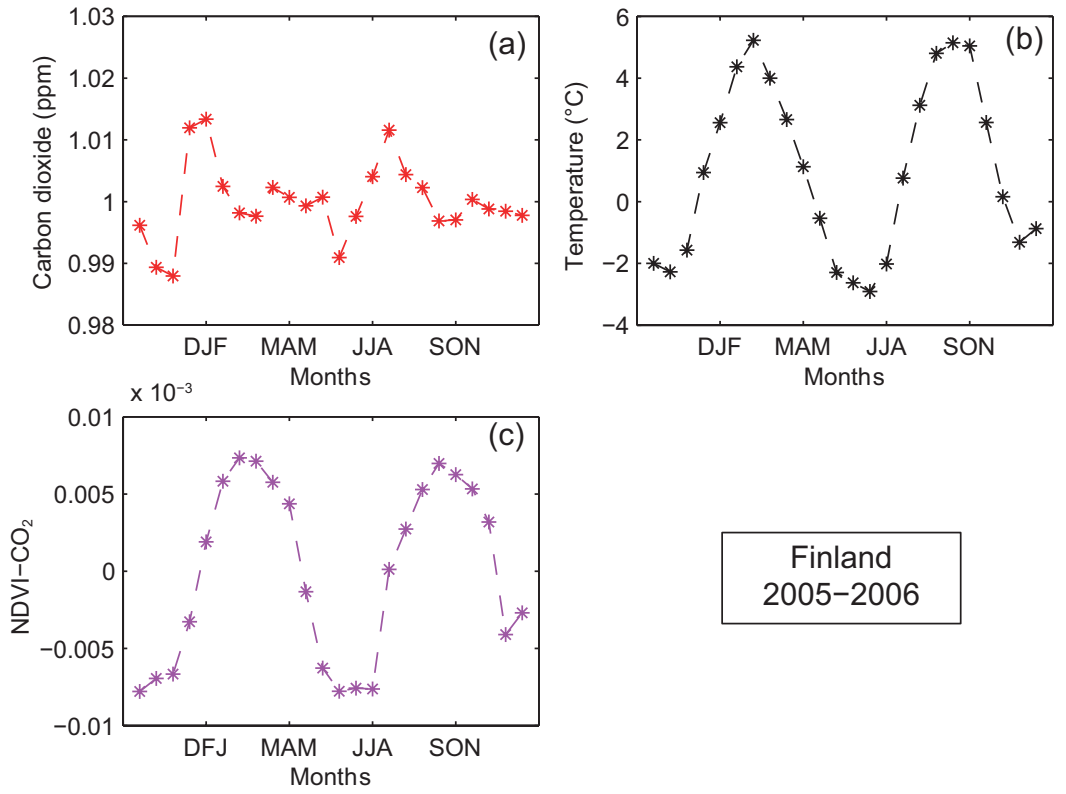

Finland 2005-2006

Fig. 18. Seasonal trend of the $\mathrm{CO}_{2}$ and NDVI relationship with temperature over Finland during the intermediate solar activity cycle. 

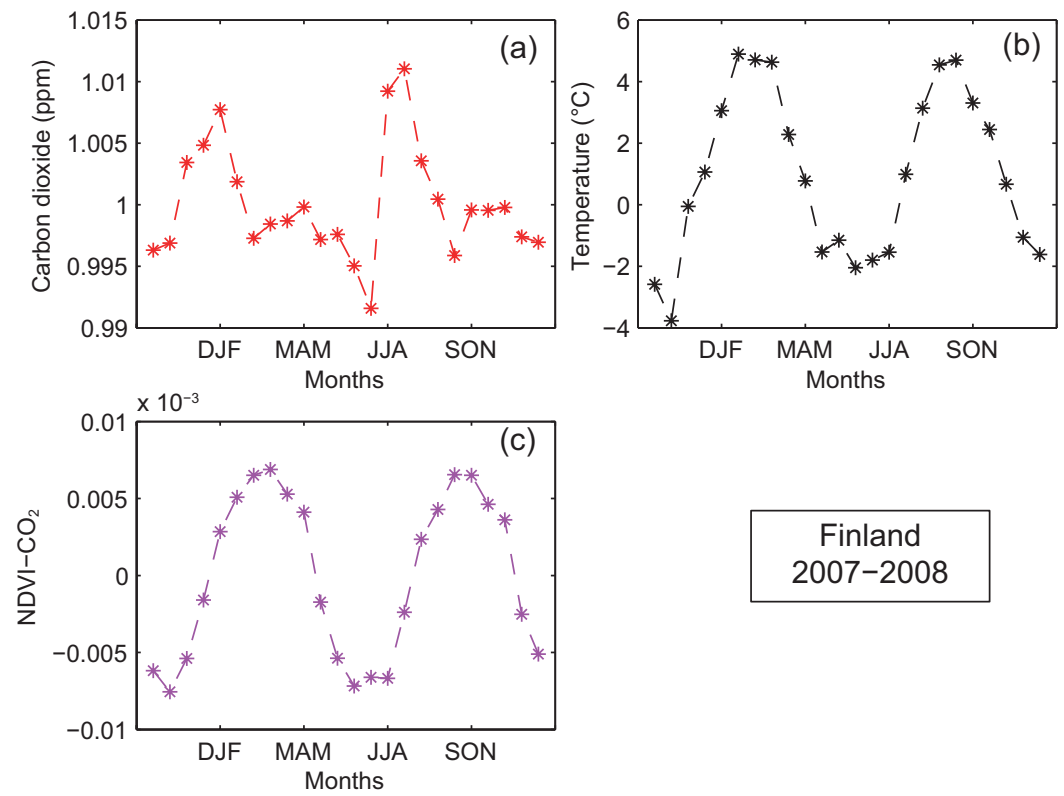

Finland 2007-2008

Fig. 19. Seasonal trend of the $\mathrm{CO}_{2}$ and NDVI relationship with temperature over Finland during the weak solar activity cycle.
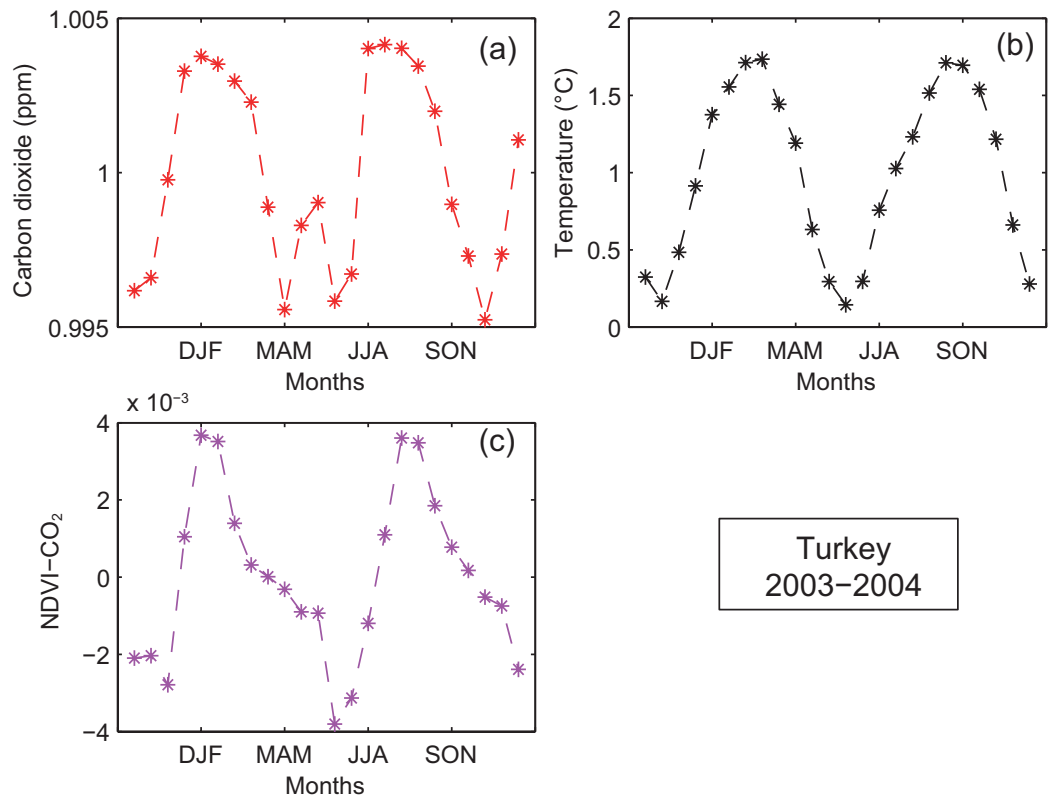

Turkey 2003-2004

Fig. 20. Seasonal trend of the $\mathrm{CO}_{2}$ and NDVI relationship with temperature over Turkey during the ascending solar activity cycle. 

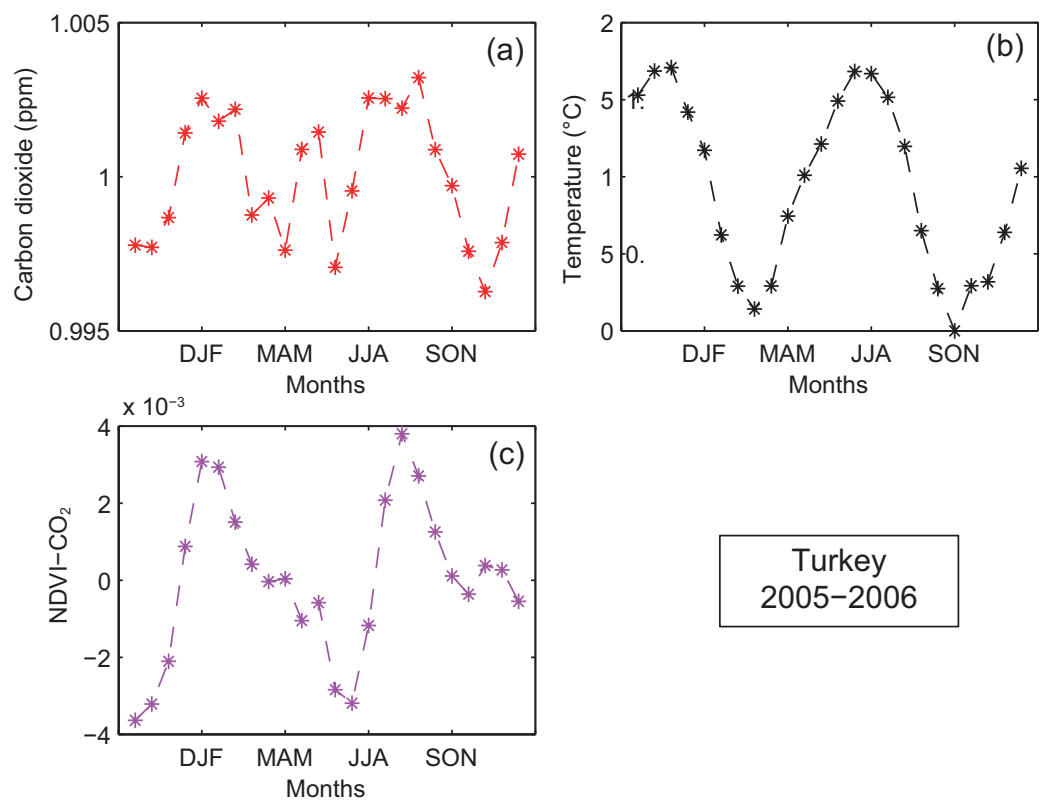

Turkey

2005-2006

Fig. 21. Seasonal trend of the $\mathrm{CO}_{2}$ and NDVI relationship with temperature over Turkey during the intermediate solar activity cycle.
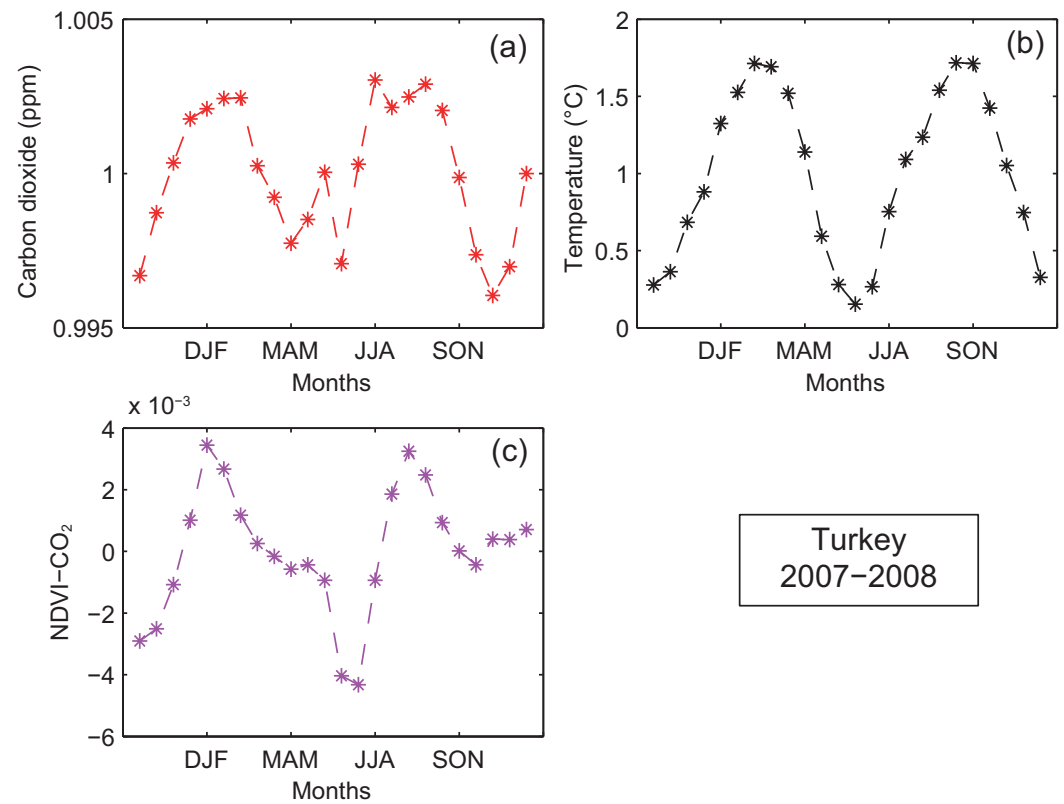

Fig. 22. Seasonal trend of the $\mathrm{CO}_{2}$ and NDVI relationship with temperature over Turkey during the weak solar activity cycle. 
concentrations of $\mathrm{CO}_{2}$ caused the region's heat wave, thereby resulting in climate change. NDVI and $\mathrm{CO}_{2}$ interactions are regional, and the range of change in climate also differs. This result is well supported by La-Puma et al. (2007). In Table III, NDVI and $\mathrm{CO}_{2}$ show a weak correlation towards the first and second years, but the moderate correlation in Turkey over the period confirms a high emission rate. In Figures $23 \mathrm{a}$ to $25 \mathrm{~b}$ there is a moderate $\mathrm{CO}_{2}$ trend due to high concentrations of NDVI.

\subsection{Asia}

TableIV shows a negative, weak correlation between NDVI and $\mathrm{CO}_{2}$ over China and Mongolia during the intermediate and weak solar activity years. This result is in agreement with Le Quere et al. (2009), as shown in Figure 27a, b, which suggests that over $30 \%$ of the $\mathrm{CO}_{2}$ concentrations in China are generated by industrial activities. However, it can be seen that the northern hemisphere is not sensitive to the dynamics of $\mathrm{CO}_{2}$ variation. Therefore, surface-based observation is recommended in this region. Additionally, the results of Murayama et al. (2004) confirm that direct measurement in the northern hemispheric zone is valuable. The
Table III. Correlation index (Europe).

\begin{tabular}{ccc}
\hline Station & & NDVI and $\mathrm{CO}_{2}$ \\
\hline 2003-2004 & France & 0.34 \\
$2005-2006$ & & 0.11 \\
$2007-2008$ & & 0.29 \\
& Finland & 0.32 \\
$2003-2004$ & & 0.27 \\
$2005-2006$ & & 0.06 \\
$2007-2008$ & & \\
$2003-2004$ & Turkey & 0.69 \\
$2005-2006$ & & 0.62 \\
$2007-2008$ & & 0.58 \\
$2003-2004$ & Ukraine & 0.47 \\
$2005-2006$ & & 0.28 \\
$2007-2008$ & & 0.48 \\
\hline
\end{tabular}

results of this study contribute to this knowledge gap. Figures 28 to 35 show a moderate trend of $\mathrm{CO}_{2}$ as a result of an increase in NDVI during winter and autumn. Towards the intermediate solar activity year over India and Afghanistan (Figs. 33 to 37 ) and the weak solar activity year over this last
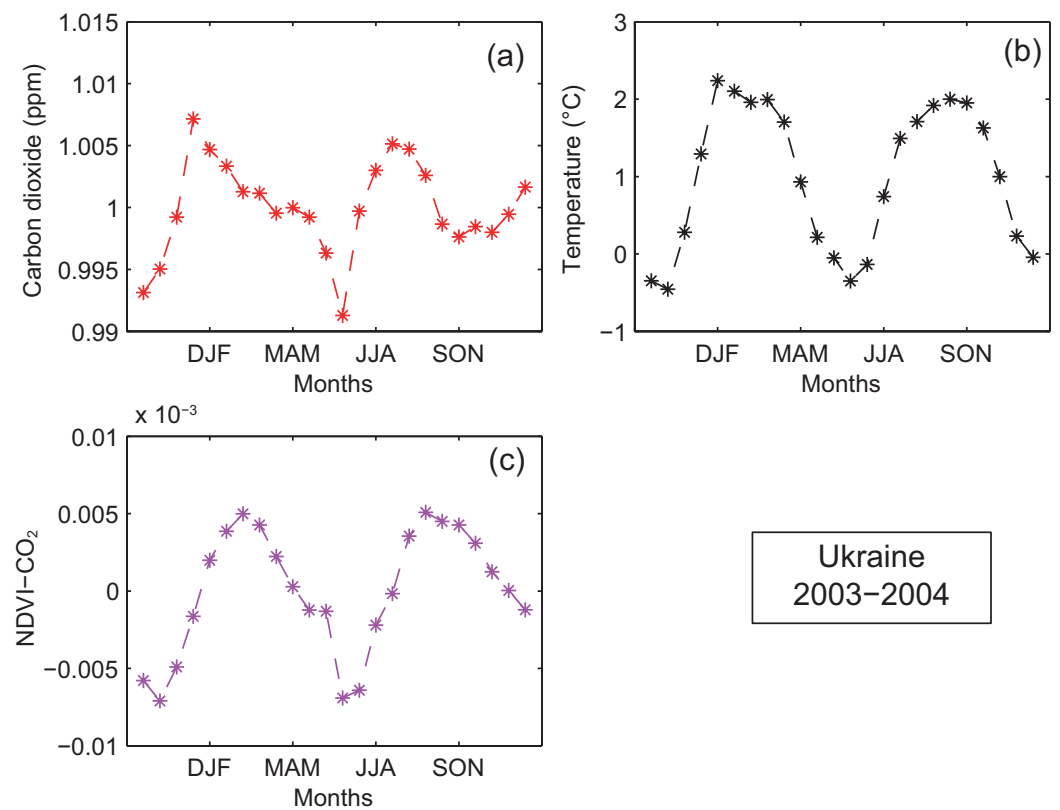

Ukraine 2003-2004

Fig. 23. Seasonal trend of the $\mathrm{CO}_{2}$ and NDVI relationship with temperatur over Ukraine during the ascending solar activity cycle. 

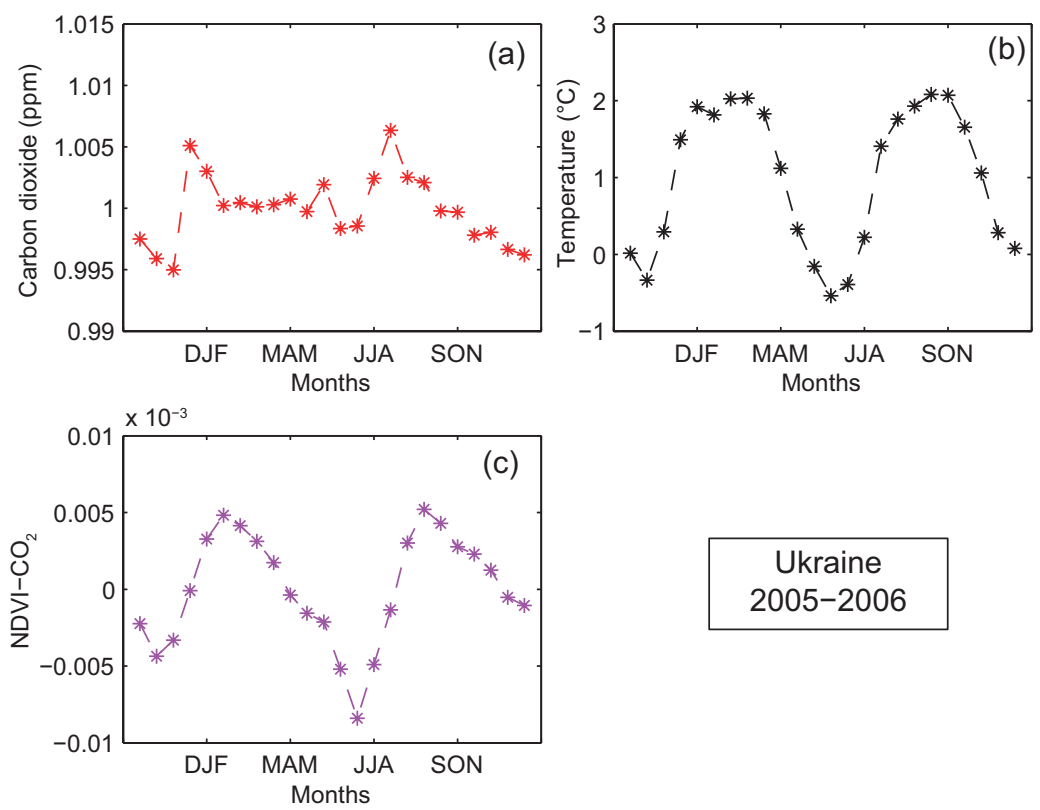

Ukraine

2005-2006

Fig. 24. Seasonal trend of the $\mathrm{CO}_{2}$ and NDVI relationship with temperature over Ukraine during the intermediate solar activity cycle.
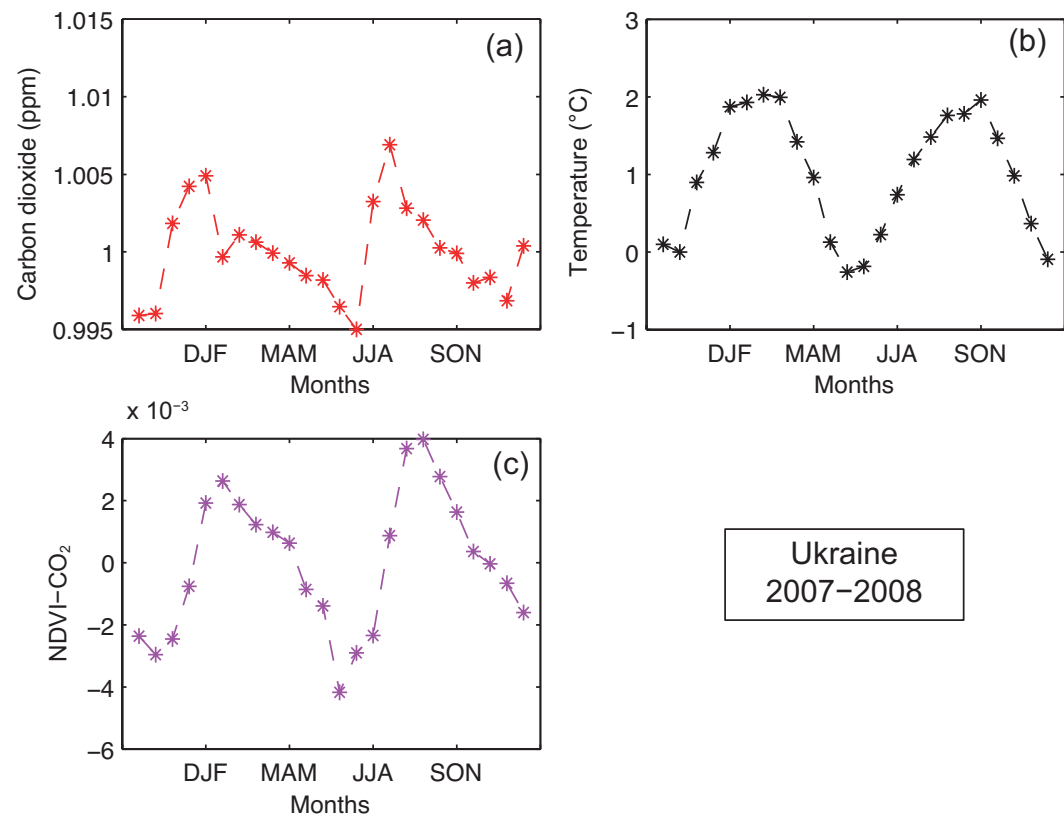

Fig. 25. Seasonal trend of the $\mathrm{CO}_{2}$ and NDVI relationship with temperature over Ukraine during the weak solar activity cycle. 
Table IV. Correlation index (Asia).

\begin{tabular}{ccc}
\hline Station & \multicolumn{2}{c}{ NDVI and $\mathrm{CO}_{2}$} \\
\hline 2003-2004 & China & 0.12 \\
$2005-2006$ & & -0.07 \\
$2007-2008$ & & -0.22 \\
& Mongolia & 0.60 \\
$2003-2004$ & & 0.40 \\
$2005-2006$ & & 0.51 \\
$2007-2008$ & & \\
& India & -0.59 \\
$2003-2004$ & & -0.65 \\
$2005-2006$ & & -0.69 \\
$2007-2008$ & & 0.83 \\
& Afghanistan & 0.52 \\
$2003-2004$ & & 0.61 \\
$2005-2006$ & & \\
$2007-2008$ & & \\
\hline
\end{tabular}
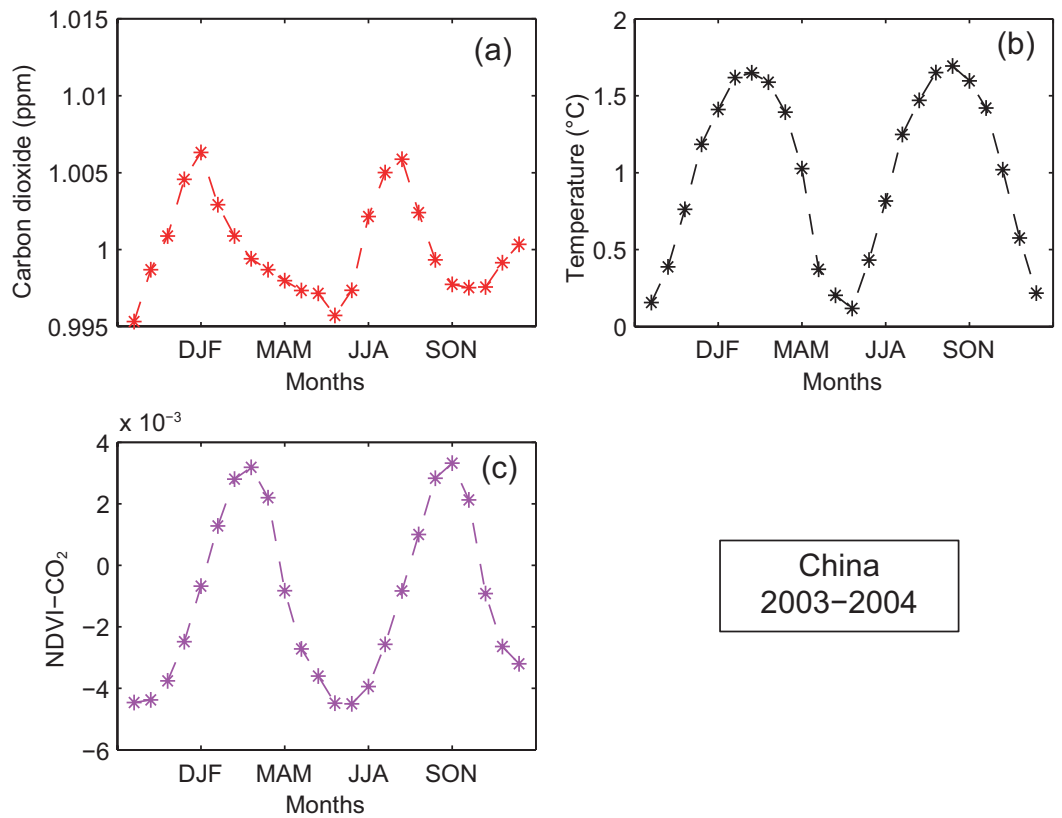

Fig. 26. Seasonal trend of the $\mathrm{CO}_{2}$ and NDVI relationship with temperature over China during the ascending solar activity cycle. 

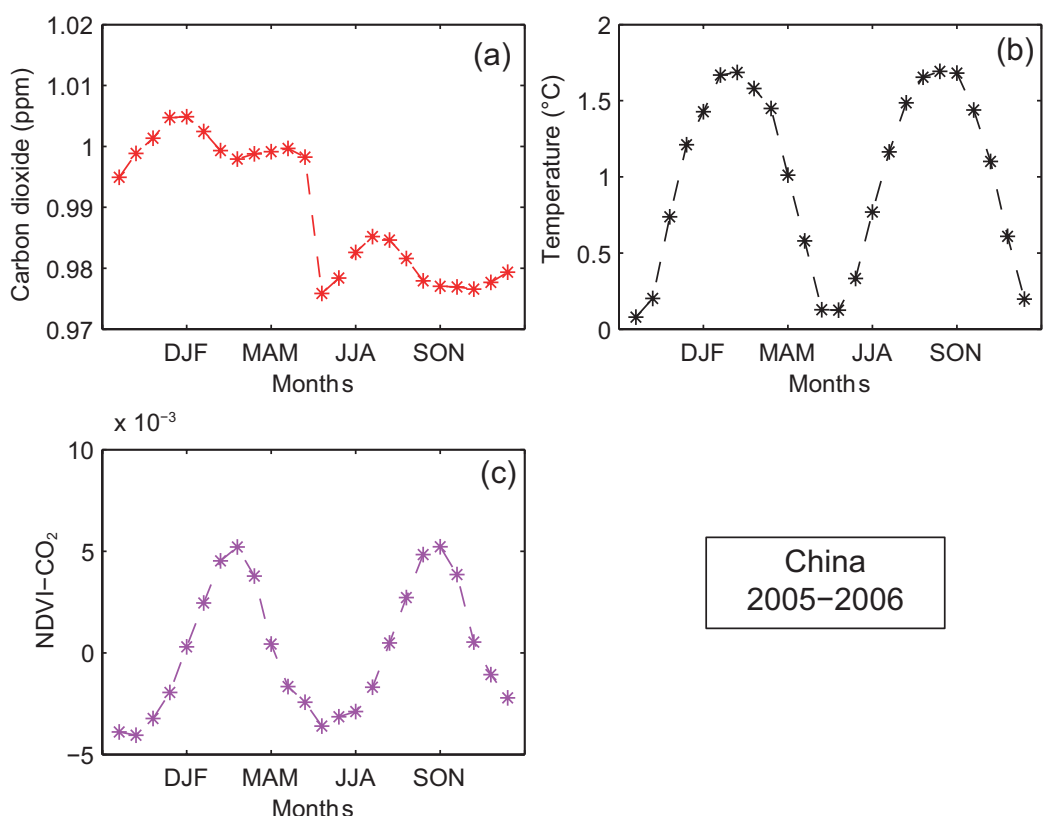

Fig. 27. Seasonal trend of the $\mathrm{CO}_{2}$ and NDVI relationship with temperature over China during the intermediate solar activity cycle.
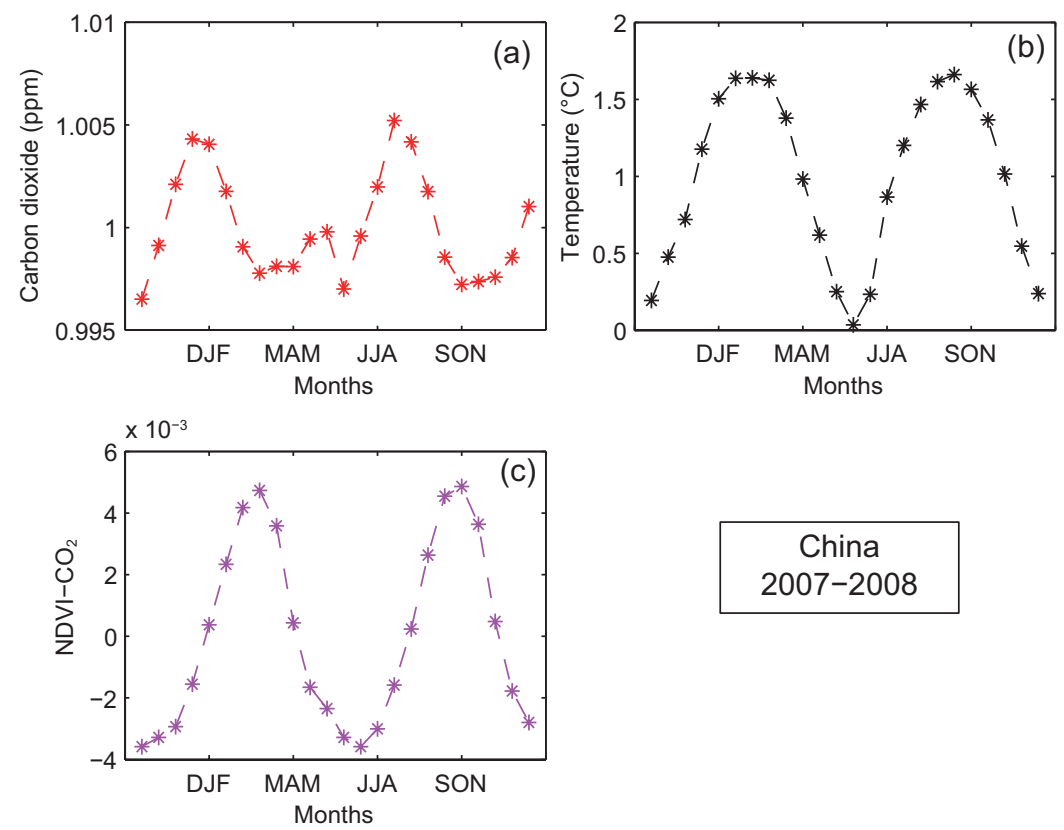

Fig. 28. Seasonal trend of the $\mathrm{CO}_{2}$ and NDVI relationship with temperature over China during the weak solar activity cycle. 

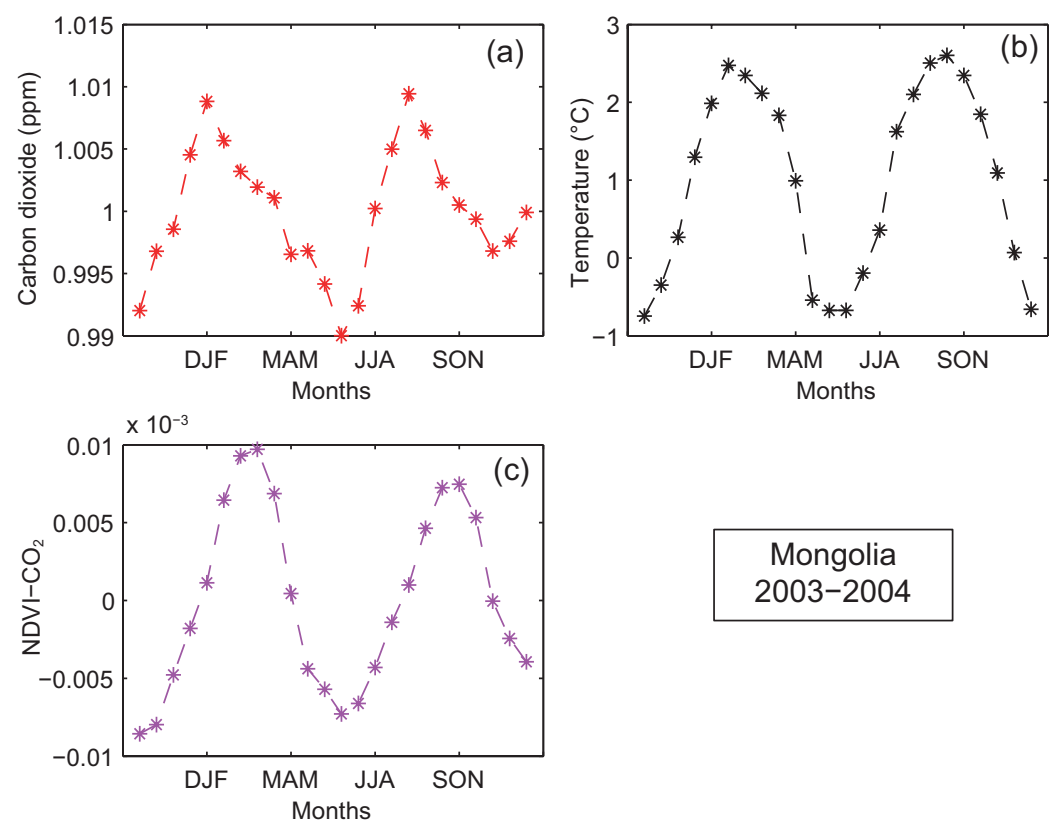

Mongolia 2003-2004

Fig. 29. Seasonal trend of the $\mathrm{CO}_{2}$ and NDVI relationship with temperature over Mongolia during the ascending solar activity cycle.
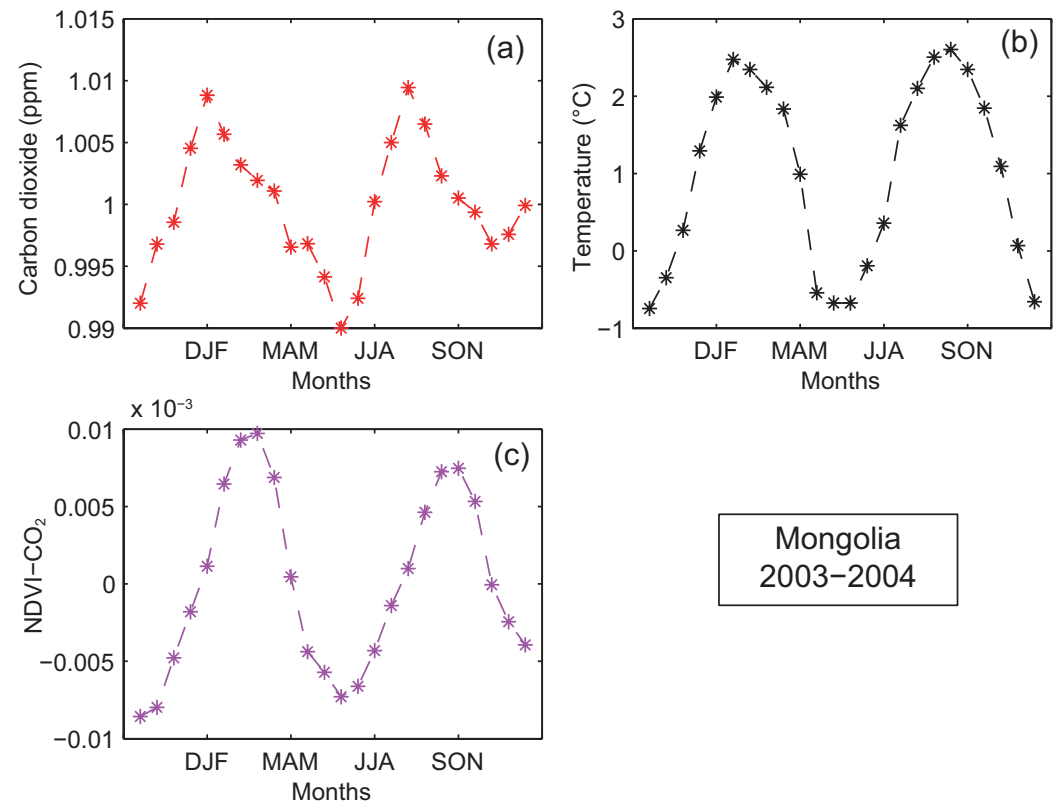

Fig. 30. Seasonal trend of the $\mathrm{CO}_{2}$ and NDVI relationship with temperature over Mongolia during the intermediate solar activity cycle. 



Mongolia

2005-2006

Fig. 31. Seasonal trend of the $\mathrm{CO}_{2}$ and NDVI relationship with temperature over Mongolia during the weak solar activity cycle.
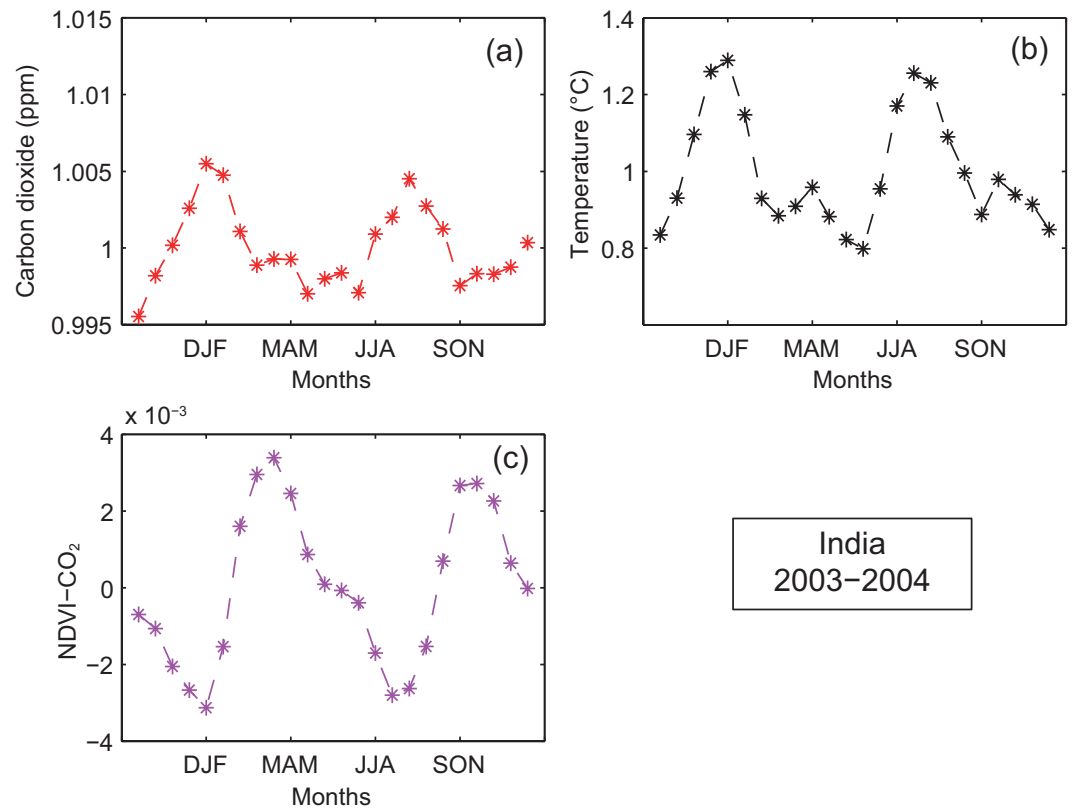

India

2003-2004

Fig. 32. Seasonal trend of the $\mathrm{CO}_{2}$ and NDVI relationship with temperature over India during the ascending solar activity cycle. 

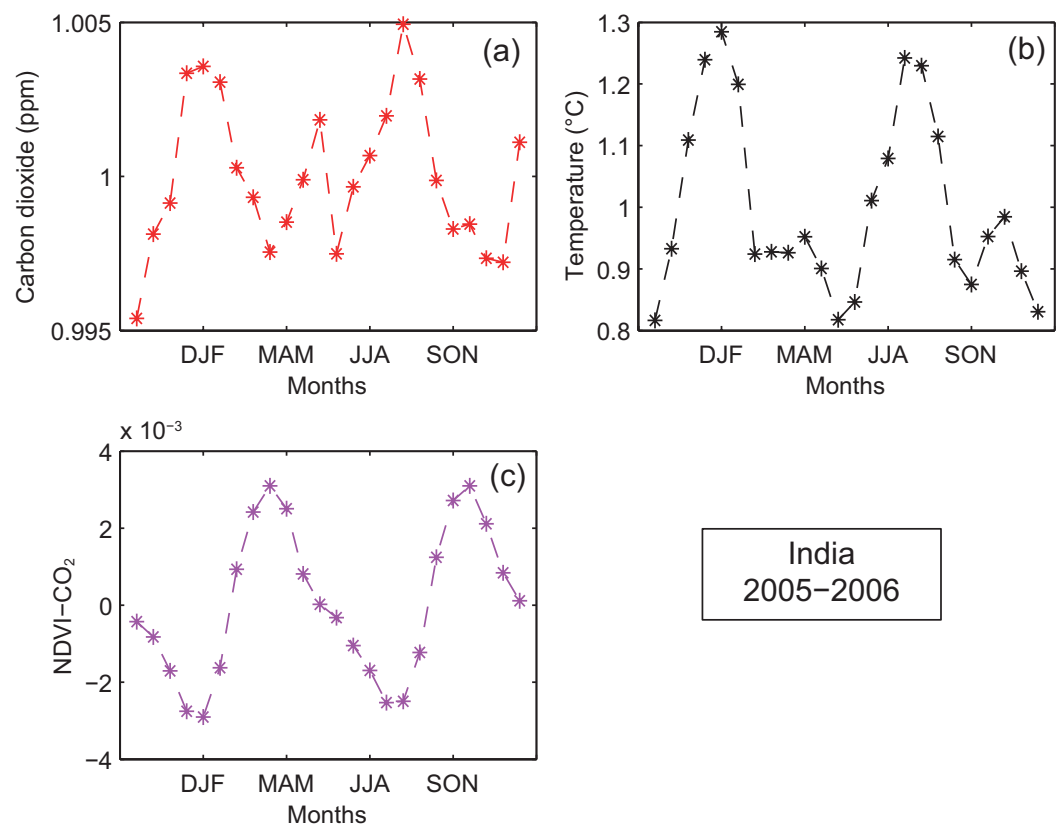

India

2005-2006

Fig. 33. Seasonal trend of he $\mathrm{CO}_{2}$ and NDVI relationship with temperature over India during the intermediate solar activity cycle.
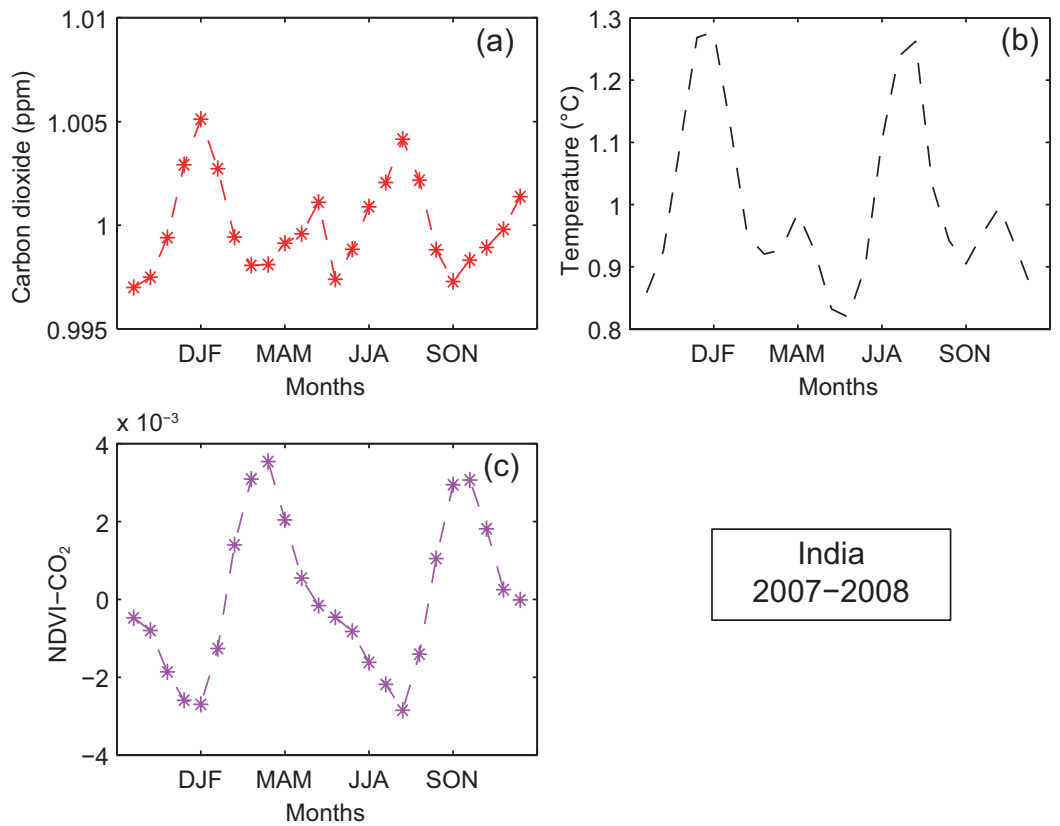

Fig. 34. Seasonal trend of the $\mathrm{CO}_{2}$ and NDVI relationship with temperature over India during the weak solar activity cycle. 

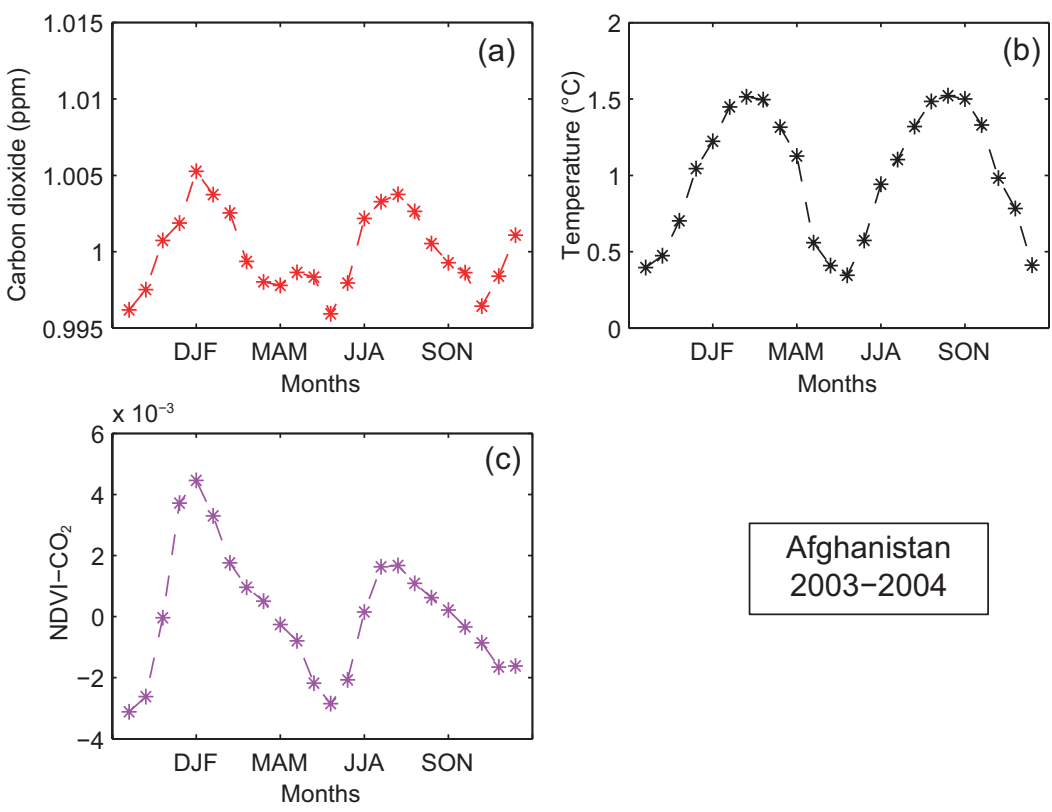

Afghanistan

2003-2004

Fig. 35. Seasonal trend of the $\mathrm{CO}_{2}$ and NDVI relationship with temperature over Afghanistan during the ascending solar activity cycle.
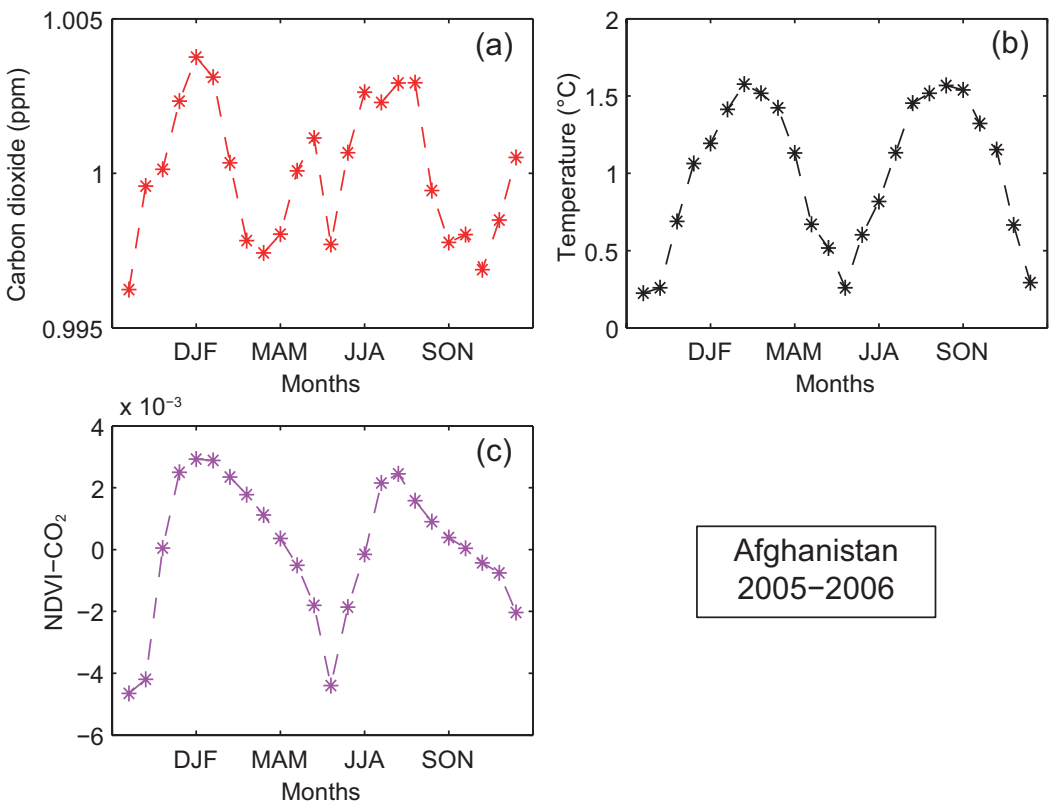

Afghanistan 2005-2006

Fig. 36. Seasonal trend of the $\mathrm{CO}_{2}$ and NDVI relationship with temperature over Afghanistan during the intermediate solar activity cycle. 

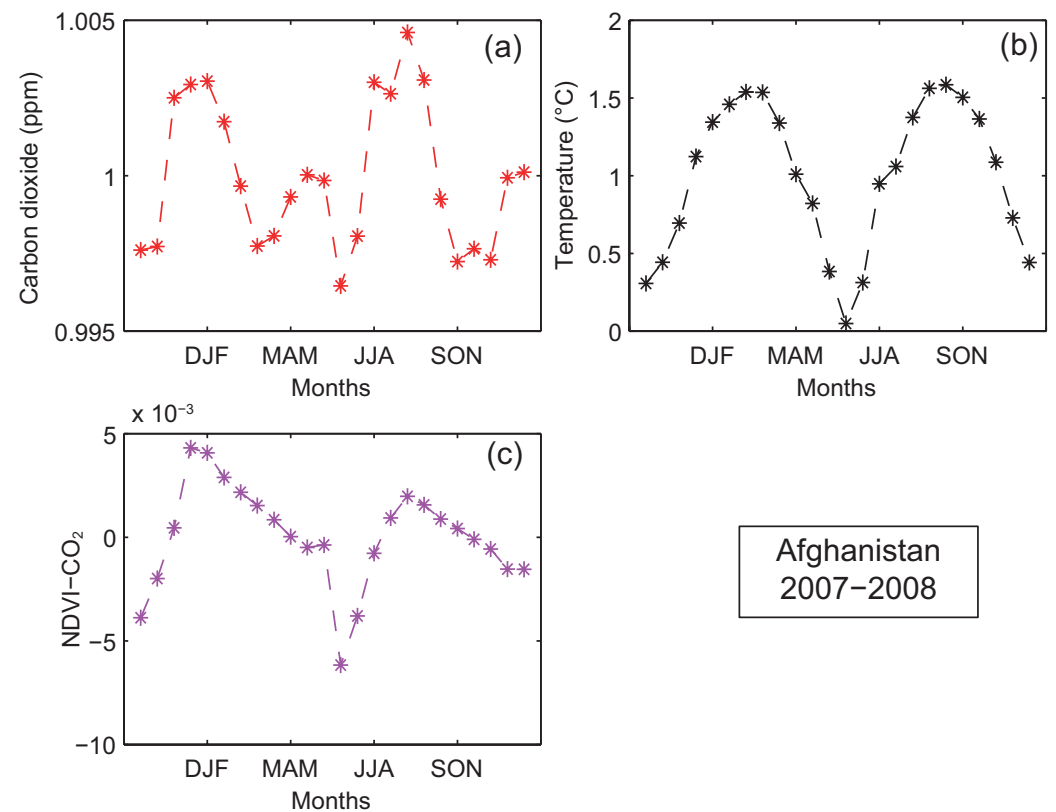

\section{Afghanistan} 2007-2008

Fig. 37. Seasonal trend of the $\mathrm{CO}_{2}$ and NDVI relationship with temperature over Afghanistan during the weak solar activity cycle.

country, there is a seasonal trend of $\mathrm{CO}_{2}$ increase indicating high atmospheric accumulation leading to climate variability.

\section{Conclusion and policy recommendation}

This study presents a combined assessment of continental $\mathrm{CO}_{2}$ dominance and seasonal changes. The results show that the sequestration of $\mathrm{CO}_{2}$ using greening is essential to maintain moderate atmospheric conditions. However, the study has revealed that the continental biomass burning rate is seasonally dependent and varies regionally. The variability of seasonally integrated NDVI presents a consistent picture of the green index and carbon mitigation rate across a region. The seasonal mean is valuable to enable the regional investigation of carbon concentration using vegetation index, in order to document seasonal responses to high carbon atmospheric content (Heiman et al. 1998). However, our results were also compared to the corresponding temperature variations. The seasonal changes of NDVI correspond to a terrestrial sink of regional $\mathrm{CO}_{2}$, mostly occurring during equinoctial months
(Piao et al., 2008; Vesala et al., 2010). Additionally, the dynamical responses of rapid carbon concentration resulting from biomass burning have broad spatial and temporal extent. The regression analysis shows that Africa and Asia are the largest $\mathrm{CO}_{2}$ contributors, with an inverse relationship which indicates coupling of $\mathrm{CO}_{2}$ and NDVI. An extended validation including more regions is needed in future works, to better characterize the drivers of variability in $\mathrm{CO}_{2}$ time series.

1. The seasonal investigation of $\mathrm{CO}_{2}$ renders the direct atmospheric composition, which is similar to the results of Conway et al. (1994).

2. The seasonal variation of $\mathrm{CO}_{2}$ from the results of the present study analysis depends on geographic latitude.

3. The seasonal index analysis is better to analyze the trends in atmospheric $\mathrm{CO}_{2}$ variation.

\section{Acknowledgments}

I appreciate MODIS team at NASA for the provision of satellite data, and Dr. Dan Killam of University of 
Haifa for English revision. The comments and suggestions by both the editor and the reviewers, which led to considerable improvement in the presentation of the ideas and results of this paper, are very well appreciated.

\section{References}

Barchivich J, Briffa K, Myneni R, Osborn T, Melvin T, Ciais P, Piao S, Tucker C. 2013. Large- scale variations in the vegetation growing season and annual cycle of atmospheric $\mathrm{CO}_{2}$ at high northern latitudes from 1950 to 2011. Global Change Biology 10:3167-3183. https:// doi.org/10.1111/gcb.12283

Bartlett DS, Whiting GJ, Hartman JM. 1990. Use of vegetation indices to estimate intercepted solar radiation and net carbon dioxide exchange of a grass canopy. Remote Sensing of Environment 30:115-128. https:// doi.org/10.1016/0034-4257(89)90054-0

Battle M, Bender ML, Tans PP, White JWC, Ellis JT, Conway T, Francey RJ. 2000. Global carbon sinks and their variability inferred from atmospheric $\mathrm{O}_{2}$ and $\delta C^{13}$. Science 287:2467- 2470. https://doi: $10.1126 /$ science.287.5462.2467

Boelman NT, Stieglitz M, Reuth H, Sommerkorn M, Griffin K, Shaver GR, Gamon JA. 2003. Response of NDVI, biomass, and ecosystem gas exchange to long-term warming and fertilization in wet sedge tundra. Oecologia 135:414-421. https://doi.org/10.1007/ s00442- 003-1198-3.

Buermann WBR, Lintner CD, Koven A, Angert JE, Pinzon CJ, Tucker CL, Fung IY. 2007. The changing carbon cycle at Mauna Loa observatory. Proceedings of $\mathrm{Na}$ tional Academy of Science 104:4249-4254. https://doi. org/10.1073/pnas.0611224104

Chen X, Xu C, Tan Z. 2001. An analysis of relationships among plant community phenology and seasonal metrics of Normalized Difference Vegetation Index in the northern part of the monsoon region of China. International Journal of Biometeorology 45:170-177. https://doi.org/10.1007/s004840100102

Cihlar J, Caromori PH, Schuepp PH, Desjardins TL, MacPherson JL. 1992. Relationships between satellite-derived indices and aircraft-based $\mathrm{CO}_{2}$ measurements. Journal of Geophysical Research 97:18522-18525. https://doi.org/10.1029/92JD00655

Conway TJ, Tans P, Waterman LS, Thoning KW, Buanerkitzis DR, Masarie KA, Zhang N.1994
Evidence for interannual variability of the carbon cycle from the NOAA/CMDLglobal air sampling network. Journal of Geophysical Research 99:22831-22855. https://doi.org/10.1029/94JD01951

Curtis PS, Wang X. 1998. A meta-analysis of elevated $\mathrm{CO}_{2}$ effects on woody plant Mass, form, and physiology. Oecologia 113:299-313. https://doi.org/10.1007/ s004420050381

Dagg J, Lafleur P. 2014. An application of plot-scale NDVI in predicting carbon dioxide exchange and leaf area index in heterogeneous subarctic tundra. Canadian Journal of Remote Sensing 36:S111-S123. https://doi. org $/ 10.5589 / \mathrm{m} 10-019$

Ferreira LG, Yoshiokaa H, Huetea A, Sano EE. 2003. Seasonal landscape and spectral vegetation index dynamics in the Brazilian Cerrado: An analysis within the Large-Scale Biosphere Atmosphere Experiment in Amazo^nia (LBA). Remote Sensing Environment 87 :534-550. https://doi.org/10.1016/j.rse.2002.09.003

Guo M, Wang X, Li J, Yi K, Zhong G, Tani H. 2012. Assessment of Global Carbon Dioxide Concentration Using MODIS and GOSAT Data. Sensors 12:1636816389. https://doi.org/10.3390/s121216368

Heimann M, Esser G, Haxeltine A, Kaduk J, Kicklighter DW, Knorr W, Kohlmaier GH, McGuire AD, Melillo J, Moore III B, Ottofi RD, Prentice IC, Sauf W, Schloss A, Sitch S, Wittenberg U, Wtir G. 1998. Evaluation of terrestrial carbon cycle models through simulat- ions of the seasonal cycle of atmosphericCO $\mathrm{CO}_{2}$ : First results of a model intercomparison study. Global Biological Cycle 12:1-24. https://doi.org/10.1029/97GB01936

Hope AS, Kimball JS, Stow DA. 1993. The relationship between tussock tundra spectral reflectance properties and biomass and vegetation composition. International Journal of Remote Sensing 14:1861-1874. https://doi. org/10.1080/01431169308954008

Houghton RA, Hackler JL. 1999. Emissions of carbon from forestry and land-use change in tropical Asia. Global Change Biology 5:481-492. https://doi. org/10.1046/j.1365- 2486.1999.00244.x

Huete A, Didan K, Miura T, Rodriguez EP, Gao X, Ferreira LG. 2002. Overview of the radiometric and biophysical performance of the MODIS vegetation indices. Remote Sensing Environment 83:195-213. https:// doi.org/10.1016/S0034-4257(02)00096-2

Kaplan LD. 1960. The Influence of Carbon Dioxide Variations on the Atmospheric Heat Balance. Tellus 12:204-208. https://doi.org/10.3402/tellusa.v13i2.9444 
Kaufmann RK, Paletta LF, Tian HQ, Myneni RB, D'Arrigo RD. 2008. The Power of Monitoring Stations and a $\mathrm{CO}_{2}$ Fertilization Effect: Evidence from Causal Relationships between NDVI and Carbon Dioxide. Earth Interactions 9:1-23. https://doi. org/10.1175/2007EI240.1

Komhyr WD, Harris TB, Waterman LS, Chin JFS, Thoning KW. 1989. Atmospheric carbon dioxide at Mauna Loa Observatory: 1. NOAA GMCC measurements with a non-dispersive infrared analyzer 1974-1985. Journal of Geophysical Research 94:8533-8547. https://doi. org/10.1029/JD094iD06p08533

La-Puma IP, Philippi TE, Oberbauer SF. 2007. Relating ndvi to ecosystem $\mathrm{CO}_{2}$ exchange patterns in response to season length and soil warming manipulations in arctic Alaska. Remote Sensing Environment 109:225236. https://doi.org/10.1016/j.rse.2007.01.001

Le Quere C, Raupach M, Canadell J et al. 2009. Trends in the sources and sinks of carbon dioxide. Nature Geoscience 2:831-836. https://doi.org/10.1038/ngeo689

Le Quere C, Aumont O, Bopp L, Bousquet P, Ciais P, Francey R, Heimann M. Keeling CD, Keeling RF, Kheshgi H, Peylin P, Piper SC, Prentice IC, Rayner PJ. 2003. Two decades of ocean $\mathrm{CO}_{2}$ sink and variability. Tellus Series B-Chemical \& Physical Meteorology 55:649-656. https://doi.org/10.3402/tellusb. v55i2.16719

Lim C, Kafatis M, Megonigal P. 2004. Correlation between atmospheric $\mathrm{CO}_{2}$ concentration and vegetation greenness in North America: $\mathrm{CO}_{2}$ fertilization effect. Climate Research 28:11-22. https://doi:10.3354/cr028011

Manning AC, Keeling RF. 2006. Global oceanic and land biotic carbon sinks from the Scripps atmospheric oxygen flask sampling network. Tellus Series B-Chemical and Physical Meteorology 58:95-116. https://doi. org/10.1111/j.1600-0889.2006.00175.x

Markon CJ, Peterson KM. 2002. The utility of estimating net primary productivity over Alaska using baseline AVHRR data. International Journal of Remote Sensing 23:4571-4596. https://doi. org/10.1080/01431160110113926

McKain K, Wofsy SC, Nehrkorn T, Eluszkiewicz J, Ehleringer R, Stephens B. 2012. Assessment of ground-based atmospheric observations for verification of greenhouse gas emissions from an urban region. Proceedings of the National Academy of Science of Science109:8423- 8428. https://doi.org/10.1073/ pnas. 1116645109
McMichael CE. 1999. Estimating $\mathrm{CO}_{2}$ exchange at two sites in Arctic tundra ecosystems during the growing season using a spectral vegetation index. International Journal of Remote Sensing 20:638-698. https://doi. org/10.1080/014311699213136

Murayama S, Taguchi S, Higuchi K. 2004. Interannual variation in the atmospheric $\mathrm{CO}_{2}$ growth rate: Role of atmospheric transport in the Northern Hemisphere. Journal of Geophysical Research 109:D02305. https:// doi.org/10.1029/2003JD003729

Piao S, Ciais P, Friedlingstein P et al. 2008. Net carbon dioxide losses of northern ecosystems in response to autumn warming. Nature 451:49 52. https://doi. org/10.1038/nature 06444

Plass GN. 1956. The carbon dioxide theory of climatic change. Tellus 8:140-154. https://doi.org/10.1111/j. 2153-3490.1956.tb01206.x

Rayner PJ, Enting IG, Francey RJ, Langenfelds R. 1999. Reconstructing the recent carbon cycle from atmospheric $\mathrm{CO}_{2}$, delta $\mathrm{C}^{13}$ and $\mathrm{O}_{2} / \mathrm{N}_{2}$ observations. Tellus Series B-Chemical and Physical Meteorology 51:213232. https://doi.org/10.3402/tellusb.v51i2.16273

Rigby M, Toumi R, Fisher R, Lowry D, Nisbet EG. 2008. First continuous measurements of $\mathrm{CO}_{2}$ mixing ratio in central London using a compact diffusion probe. Atmospheric Environment 42:8943-8953. https://doi. org/10.1016/j.atmosenv.2008.06.040

Rogers A, Medlyn BE, Dukes JS, Bonan G et al. 2017. A roadmap for improving the representation of atmospheric capacity and $\mathrm{CO}_{2}$ assimilation in the Arctic. New Phytologist Trust 26:705-718. https://doi.org/10.1111/nph.14283

Ruimy A, Jarvis PG, Baldocchi DD, Saugier B. 1995. CO fluxes over plant canopies and solar radiation: A review. Advances in Ecological Research 26: 1-66. https://doi. org/10.1016/S0065-2504(08)60063-X

Seekell D. 2016. Passing the point of no return. Science 354: 9 11. https://doi: 10.1126/science.a al2188

Sharkey TD. 2016. What gas exchange data can tell us about photosynthesis. Plant cell and Environment 39:1161-1173. https:// doi: 10.1111/pce.12641

Siegenthaler UJ, Sarmiento JL. 1993. Atmospheric carbon dioxide and the Ocean. Nature 9:365-375. https://doi. org/10.1038/365119a0

Stow DA, Hope AS, Boynton W, Phinn S, Walker D, Auerbach N. 1998. Satellite-derived vegetation index and cover type maps for estimating carbon dioxide flux for arctic tundra regions. Geomorphology 21:313-327. https://doi.org/10.1016/S0169-555X(97)00071-8 
Tans PP, Conway TJ, Nakazawa T. 1989. Latitudinal distribution of the sources and sinks of atmospheric carbon-dioxide derived from surface observations and an atmospheric transport model. Journal of Geophysical Research-Atmosphere 94: 5151-5172. https://doi. org/10.1029/JD094iD04p05151

Turnbul JC, Karion A, Fischer ML, Faloona I, Guilderson T, Lehman SJ, Miller BR, Miller JB, Montzka S, Sherwood T, Saripalli S, Sweeney C, Tans PP . 2011. Assessment of fossil fuel carbon dioxide and other anthropogenic trace gas emissions from airborne measurements over Sacramento, California in spring 2009. Atmospheric Chemistry and Physics 11:705-721. https://doi:10.5194/acp-11-705-2011
Vesala T, Launiainen S, Kolari P, Pumpanen J, Sevanto S, Hari P, Nikinmaa E, Kaski P, Mannila H, Ukkonen E, Piao SL, Ciais P. 2010. Autumn temperature and carbon balance of a boreal scots pine forest in Southern Finland. Biogeosciences 7:163-176. https://doi. org/10.5194/bg- 7-163-2010

Weber CL, Peters GP, Guan D, Hubacek K. 2008. The contribution of Chinese exports to climate change. Energy Policy 36:3572-3577. https://doi.org/10.1016/j. enpol.2008.06.009

Xiao X, Hollinger D, Aber A, Goltz M, Davidson EA, Zhang, X, Moore III B. 2004. Satellite- based modeling of gross primary production in an evergreen needleleaf forest. Remote Sensing Environment 89:519-534. https://doi.org/10.1016/j.rse.2003.11.008 